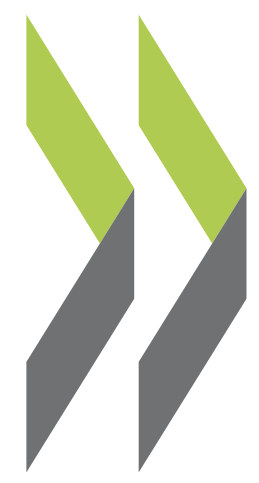

OECD Economics Department Working Papers No. 1315

\title{
Priorities for completing the European Union's Single \\ Market
} Jan Stráský 
Organisation de Coopération et de Développement Économiques

Organisation for Economic Co-operation and Development

20-Jul-2016

ECONOMICS DEPARTMENT

English - Or. English

Cancels \& replaces the same document of 06 July 2016

\section{PRIORITIES FOR COMPLETING THE EUROPEAN UNION'S SINGLE MARKET}

ECONOMICS DEPARTMENT WORKING PAPERS No. 1315

\section{By Jan Stráský}

OECD Working Papers should not be reported as representing the official views of the OECD or of its member countries. The opinions expressed and arguments employed are those of the author(s).

Authorised for publication by Robert Ford, Deputy Director, Country Studies Branch, Economics Department.

All Economics Department Working Papers are available at www.oecd.org/eco/workingpapers

JT03399375

Complete document available on OLIS in its original format

This document and any map included herein are without prejudice to the status of or sovereignty over any territory, to the delimitation of international frontiers and boundaries and to the name of any territory, city or area. 
OECD Working Papers should not be reported as representing the official views of the OECD or of its member countries. The opinions expressed and arguments employed are those of the author.

Working Papers describe preliminary results or research in progress by the author(s) and are published to stimulate discussion on a broad range of issues on which the OECD works.

Comments on Working Papers are welcomed, and may be sent to OECD Economics Department, 2 rue André Pascal, 75775 Paris Cedex 16, France, or by e-mail to eco.contact@oecd.org.

All Economics Department Working Papers are available at www.oecd.org/eco/workingpapers.

This document and any map included herein are without prejudice to the status of or sovereignty over any territory, to the delimitation of international frontiers and boundaries and to the name of any territory, city or area.

The statistical data for Israel are supplied by and under the responsibility of the relevant Israeli authorities. The use of such data by the OECD is without prejudice to the status of the Golan Heights, East Jerusalem and Israeli settlements in the West Bank under the terms of international law.

Latvia was not an OECD member at the time of preparation of this paper. Accordingly, Latvia is not included in the list of OECD countries and is not included in the area totals.

\section{(c) OECD (2016)}

You can copy, download or print OECD content for your own use, and you can include excerpts from OECD publications, databases and multimedia products in your own documents, presentations, blogs, websites and teaching materials, provided that suitable acknowledgment of OECD as source and copyright owner is given. All requests for commercial use and translation rights should be submitted to rights@oecd.org 
ECO/WKP(2016)39

\section{ABSTRACT/RÉSUMÉ Priorities for completing the European Union's Single Market}

The EU Single Market remains far from completed: progress in goods and services market integration has stalled, financial markets are still fragmented along national lines and the barriers to labour mobility remain high. Restrictive regulation within countries and regulatory heterogeneity across them hamper the internal market, reducing trade and investment flows. Network sectors, such as energy and transportation, are insufficiently interconnected and open to competition, and inefficient as a result. Reinvigorating the single market is one of the key tools to strengthen the recovery of the European Union and restore faster growth of income per capita.

To support the recovery, structural reforms that yield short-run as well as long-run gains should be prioritised. Policies enhancing labour and capital mobility are especially relevant, as they provide channels of adjustment to country-specific shocks and reinforce the effectiveness of stabilisation policies. Policies enhancing capital mobility include improved securitisation, better collection and sharing of credit information regarding smaller firms and the convergence of insolvency regimes. Labour mobility within the European Union would profit from reduced administrative and regulatory burden, such as faster recognition of professional qualifications and better portability of social and pension rights. Product markets reforms also have the potential to deliver benefits swiftly, not least by unlocking investment. Regulatory burdens could be alleviated by better impact assessment for legislative proposals and ex post evaluation of policies. Product market reforms in network sectors should include harmonisation of regulations and technical specifications, with the target of establishing single EU regulators.

This Working Paper relates to the 2016 OECD Economic Survey of the European Union (www.oecd.org/eco/surveys/economic-survey-european-union-and-euro-area.htm)

JEL classification codes: F15; F22; F36; G23; L51; L88; L98

Keywords: EU single market; economic integration; labour migration; non-bank financial institutions; Capital Markets Union; regulatory barriers; Energy Union; network services

$$
* * * * * * * * *
$$

\section{Priorités pour l'achèvement du marché unique dans l'Union Européenne}

Le marché unique de l'UE est encore loin d'être achevé : les progrès en matière d'intégration des marchés de produits et services marquent le pas, les marchés financiers demeurent fragmentés par pays et les obstacles à la mobilité de la main-d'œuvre restent nombreux. La réglementation restrictive dans les pays et l'hétérogénéité des réglementations entre eux entravent le marché intérieur, ce qui provoque une réduction des courants d'échanges et des flux d'investissement. Les industries de réseau, comme l'énergie et les transports par exemple, ne sont pas suffisamment interdépendantes et ouvertes à la concurrence, d'où leur inefficience. La redynamisation du marché unique est l'un des principaux outils pour consolider la reprise dans l'Union européenne et renouer avec une croissance plus rapide du revenu par habitant.

Pour stimuler la reprise, les réformes structurelles qui sont à l'origine de progrès à court et long terme devraient avoir la priorité. Les mesures qui renforcent la mobilité de la main-d'œuvre et des capitaux sont particulièrement importantes puisqu'elles offrent des solutions d'ajustement aux chocs propres à certains pays et améliorent l'efficacité des mesures de stabilisation. Les mesures qui renforcent la mobilité des capitaux englobent une titrisation réactivée, un recueil et un partage améliorés des données sur le crédit concernant les petites entreprises et la convergence des régimes de faillite. La mobilité de la main-d'œuvre au sein de l'Union européenne aurait tout à gagner d'une réduction de la charge administrative et du poids de la réglementation, par exemple via une reconnaissance plus rapide des qualifications professionnelles et une meilleure transférabilité des prestations sociales et droits à pension. Les réformes des marchés de produits sont aussi susceptibles d'avoir des effets positifs rapides, notamment en facilitant l'investissement. Le poids de la réglementation pourrait être allégé grâce à une analyse d'impact de meilleure qualité pour les propositions législatives et à une évaluation ex post des mesures. Les réformes des marchés de produits dans les industries de réseau devraient inclure une harmonisation des réglementations et spécifications techniques dans le but de créer une autorité de régulation unique à l'échelle de l'UE.

Ce Document de travail se rapporte à l'Étude économique de l'OCDE de l'Union Européenne (www.oecd.org/fr/eco/etudes/etude-economique-union-europeenne-et-zone-euro.htm)

Classification JEL: F15; F22; F36; G23; L51; L88; L98

Mots clef: Marché unique européen; intégration économique; migration de la main-d'œuvre; institutions financières non bancaires; union des marchés de capitaux; barrières réglementaires; union de l'énergie; industries de réseaux 


\section{TABLE OF CONTENTS}

PRIORITIES FOR COMPLETING THE EUROPEAN UNION'S SINGLE MARKET …..........................5

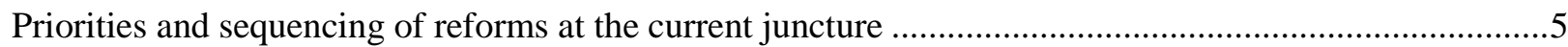

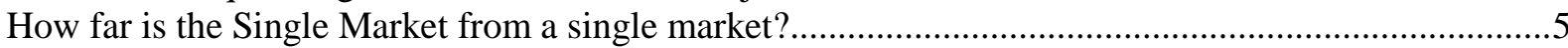

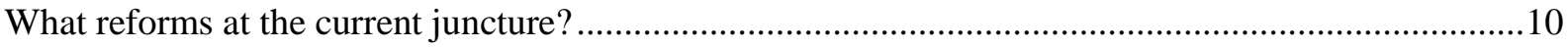

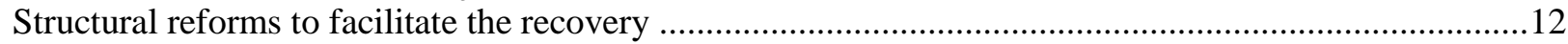

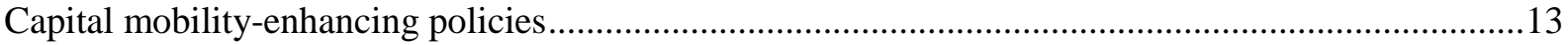

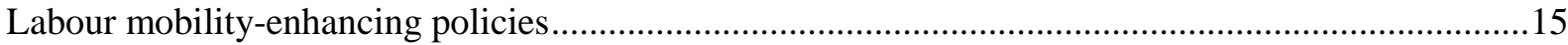

Horizontal policies to boost potential living standards ........................................................................19

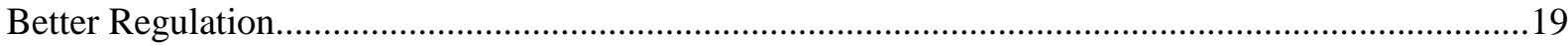

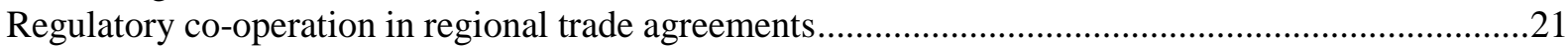

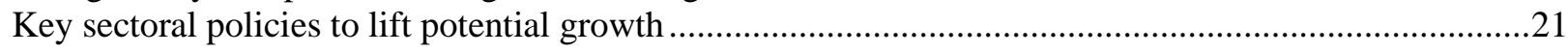

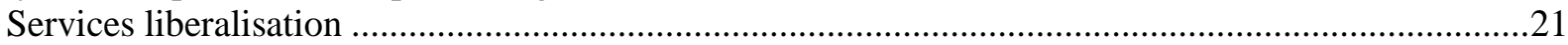

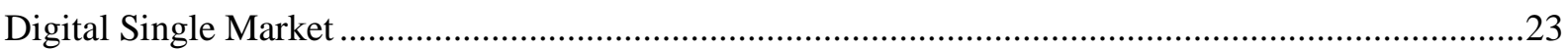

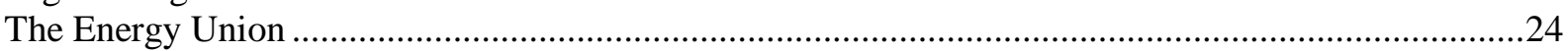

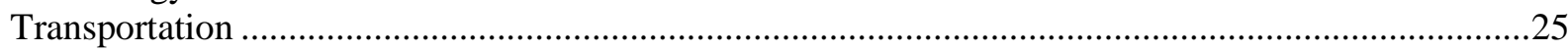

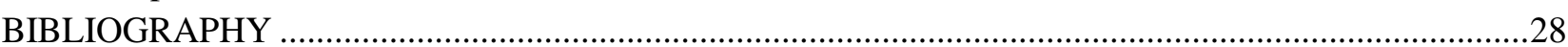

ANNEX A.1. QUANTIFICATION OF THE IMPACT OF RECOMMENDED STRUCTURAL

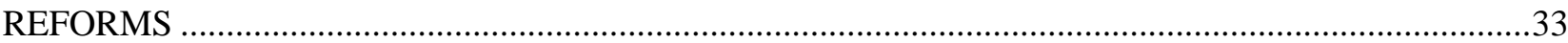

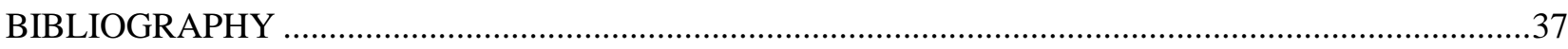

Tables

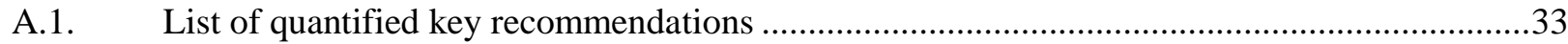

A.2. Reduction in the product market regulation (PMR) indicator ..............................................34

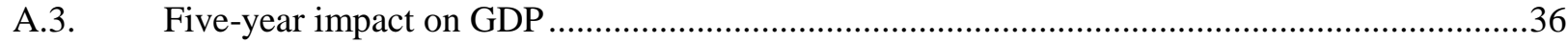

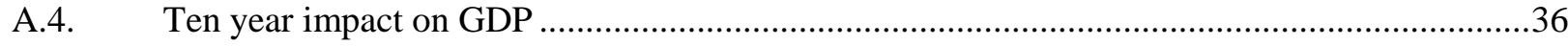

Figures

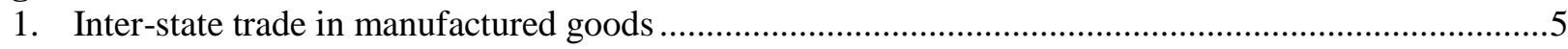

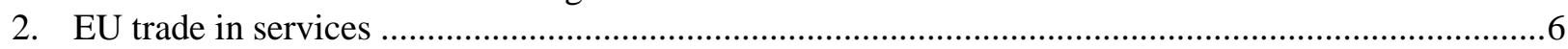

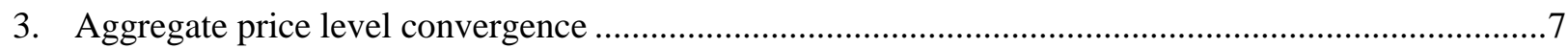

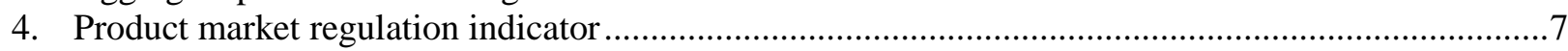

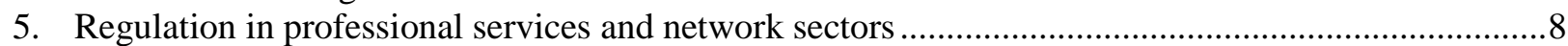

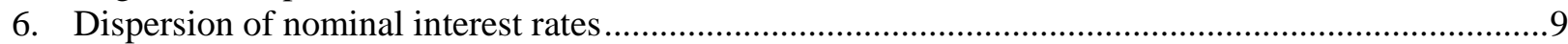

7. Cross-border positions of euro area monetary financial institutions …...............................................

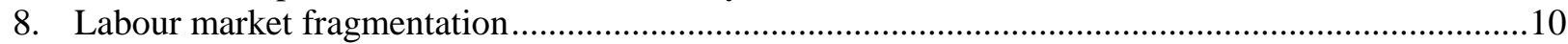

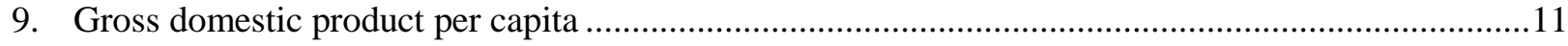

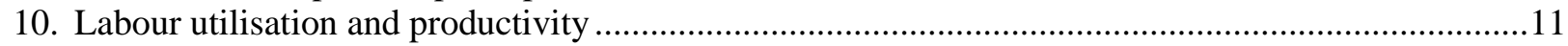

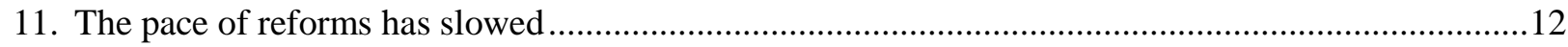

12. Bank and capital market financing of enterprises ........................................................................13

13. Asset-backed securities used in refinancing operations with the ECB .........................................14

14. Stock of migrant population within the European Union................................................................

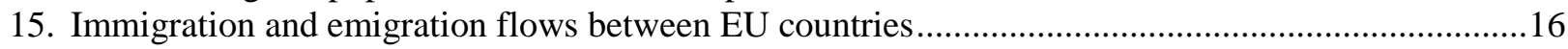

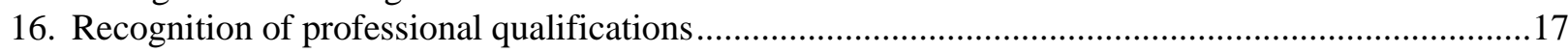

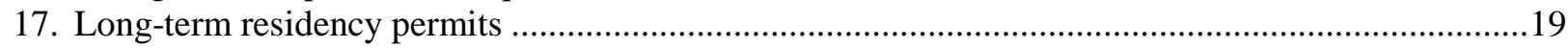

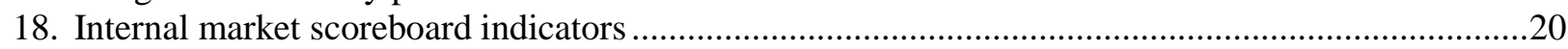

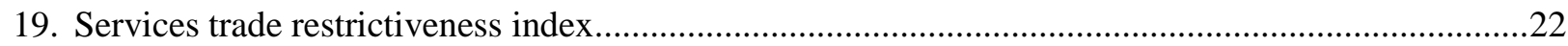

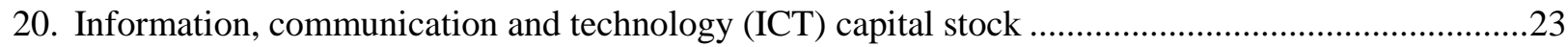

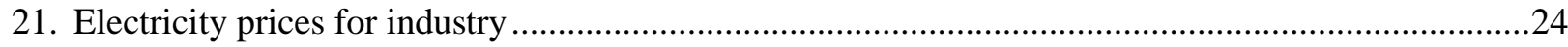

Boxes

Box 1. Recommendations on priorities for completing the Single Market.........................................26

Box A.1. Literature on the quantification of EU structural reforms .......................................................34 


\title{
PRIORITIES FOR COMPLETING THE EUROPEAN UNION'S SINGLE MARKET
}

\author{
By Jan Stráský ${ }^{1}$
}

\section{Priorities and sequencing of reforms at the current juncture}

\section{How far is the Single Market from a single market?}

Market integration in the European Union (EU) remains uneven. The goods market is the most integrated in the European Union, well beyond markets in services, capital and labour. Intra-EU trade in goods has benefited from the formation of the internal market, but progress in goods market integration seems to have stalled in the wake of the financial crisis, as intra-EU goods trade as a fraction of GDP has been roughly unchanged between 2007 and 2012 (Figure 1). Empirical evidence shows that joining the Single Market has a positive impact on trade, but that trade could be further increased by removing implicit regulatory barriers, especially heterogeneous product market regulations (Fournier et al., 2015). Intra-EU trade in manufactured goods as a share of GDP remains considerably lower than interstate trade in the United States (Figure 1).

\section{Figure 1. Inter-state trade in manufactured goods ${ }^{1}$}

As a percentage of GDP

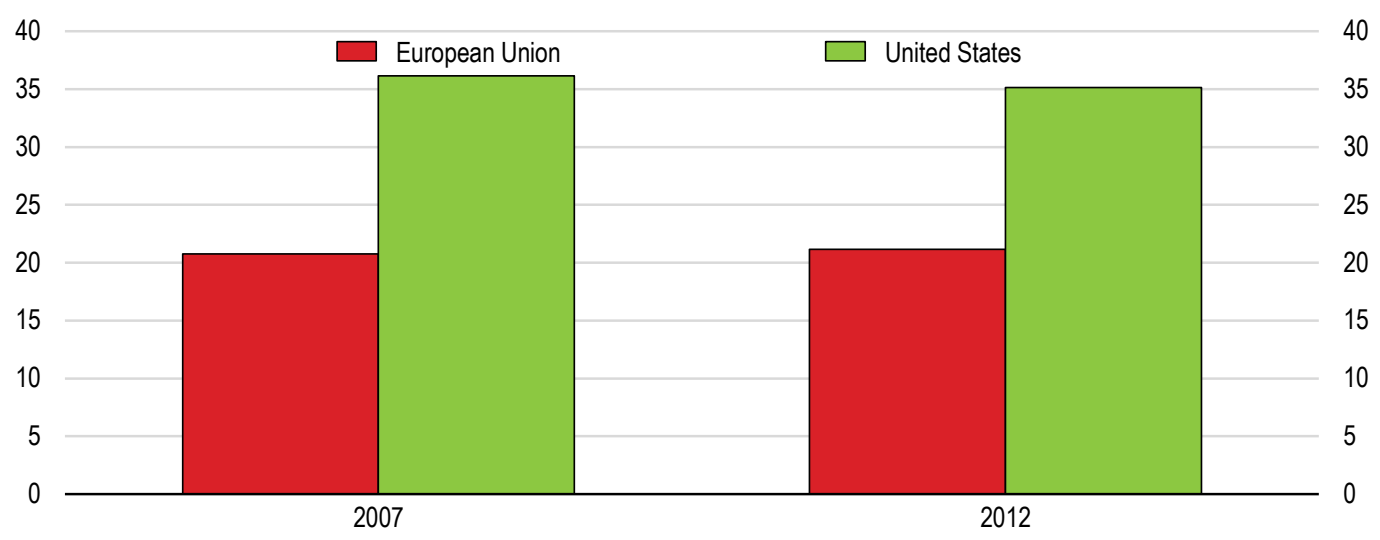

1. Data refer to trade flows among states for the United States and among EU 28 member states for the European Union.

Source: Eurostat (2015), "International trade data", Eurostat Database; US Bureau of Transportation Statistics, Commodity Flow Survey 2012 and OECD (2015), National Accounts Statistics (database).

Trade integration in services is far lower than for goods and the deepening of the internal market in services has been slow (Figure 2), despite the enactment of the Services Directive and the reduction of regulatory heterogeneity in professional services between 2008 and 2013 (Fournier, 2015). This may partly be explained by the measurement methodology. The European Union distinguishes three modes of cross-

1. Jan Stráský is an economist in the OECD Economics Department. The author is grateful to Richard Baron (OECD General Secretariat), Pierre Beynet (OECD Economics Department), Bert Brys (OECD Centre for Tax Policy and Administration), Jonathan Chaloff (OECD Directorate for Employment, Labour and Social Affairs), Robert Ford (OECD Economics Department), Peter Gal (OECD Economics Department), Thomas Liebig (OECD Directorate for Employment, Labour and Social Affairs), Thomas Neubig (OECD Centre for Tax Policy and Administration), Hidlegunn Nordas (OECD Trade and Agriculture Directorate), Álvaro Pereira (OECD Economics Department) and Álvaro Pina (OECD Economics Department) for valuable comments and suggestions on earlier drafts, as well as for discussions with European Commission and European Central Bank officials. Special thanks go to Desney Wilkinson-Erb (OECD Economics Department) for research assistance and to Amelia Godber (OECD Economics Department) and Sylvie Ricordeau (OECD Economics Department) for editorial assistance. 
border trade in services: $i$ ) trade at a distance (such as e-commerce), $i$ ) trade where the consumer crosses the border (such as tourism), and iii) trade where the supplier crosses the border (mainly covered by the Services Directive). Sales by subsidiaries of service firms located in another country do not qualify as international trade, although they probably account for the largest share of cross-border supply of services (Bénassy-Quéré et al., 2006).

Figure 2. Intra-EU trade in services

Intra EU exports of services as a percentage of GDP ${ }^{1}$

7

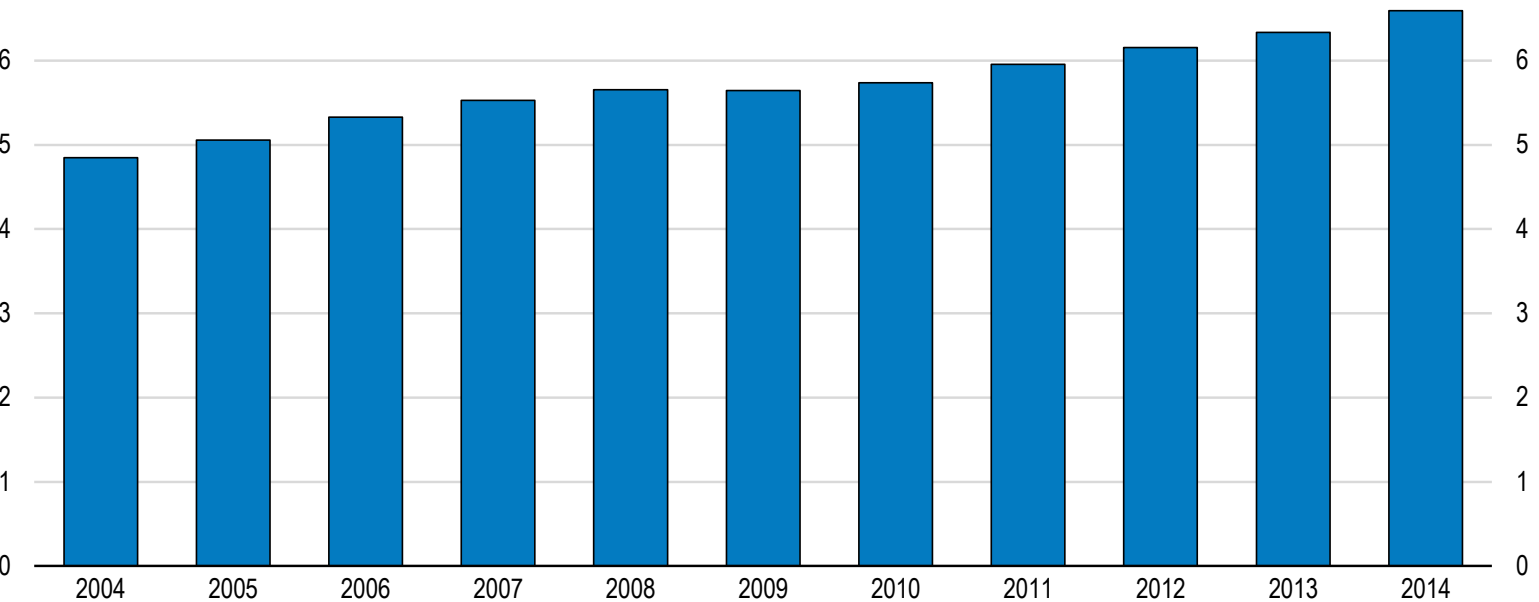

1. Balance of payments basis. Data for EU 27 countries until 2009 based on the fifth edition of the Balance of Payments methodology and data for EU 28 countries from 2010 onwards based on the sixth edition.

Source: Eurostat (2016), "Balance of payments - International transactions" and "Annual national accounts", Eurostat Database.

The progress of economic integration can be assessed by the degree of aggregate price level convergence across the areas constituting the market, such as the EU countries and the US states. As this measure combines developments in relative living standards and market integration, it has to be interpreted with caution. Prior to 2008, price convergence was considerably faster in the European Union than the euro area, but prices started to diverge in the European Union in 2009 and the price convergence has stopped in the euro area since 2012 (Figure 3). Consumers are now facing increasingly different prices for the same products in different countries. The slow progress of price convergence in the euro area has been linked to heavy regulation in the services sector, but the conjecture that the EU Services Directive may be "a stronger vector of price convergence than the single currency" (Bénassy-Quéré, 2010, p. 412) does not seem to be supported by the data. Price dispersion in the euro area remains above that among the US states, suggesting a persistent "border effect", documented in the previous work on the United States and Canada (Engel and Rogers, 1996), the OECD countries (Braconier and Pisu, 2013) and the euro area (Reiff and Rumler, 2014).

The overall indicator of product market regulation shows little improvement between 2008 and 2013 in the European Union as a whole, although changes have been significant in a few countries (Figure 4). The heterogeneity of regulation has hardly changed either (OECD, 2014a). Individual EU countries display various approaches to regulation, possibly reflecting citizens' preferences. For example, some countries combine flexible and open markets in network industries with some of the strictest regulations of professional services, but other countries do the opposite (Figure 5). 


\section{Figure 3. Aggregate price level convergence}

Coefficient of variation, per cent ${ }^{1}$

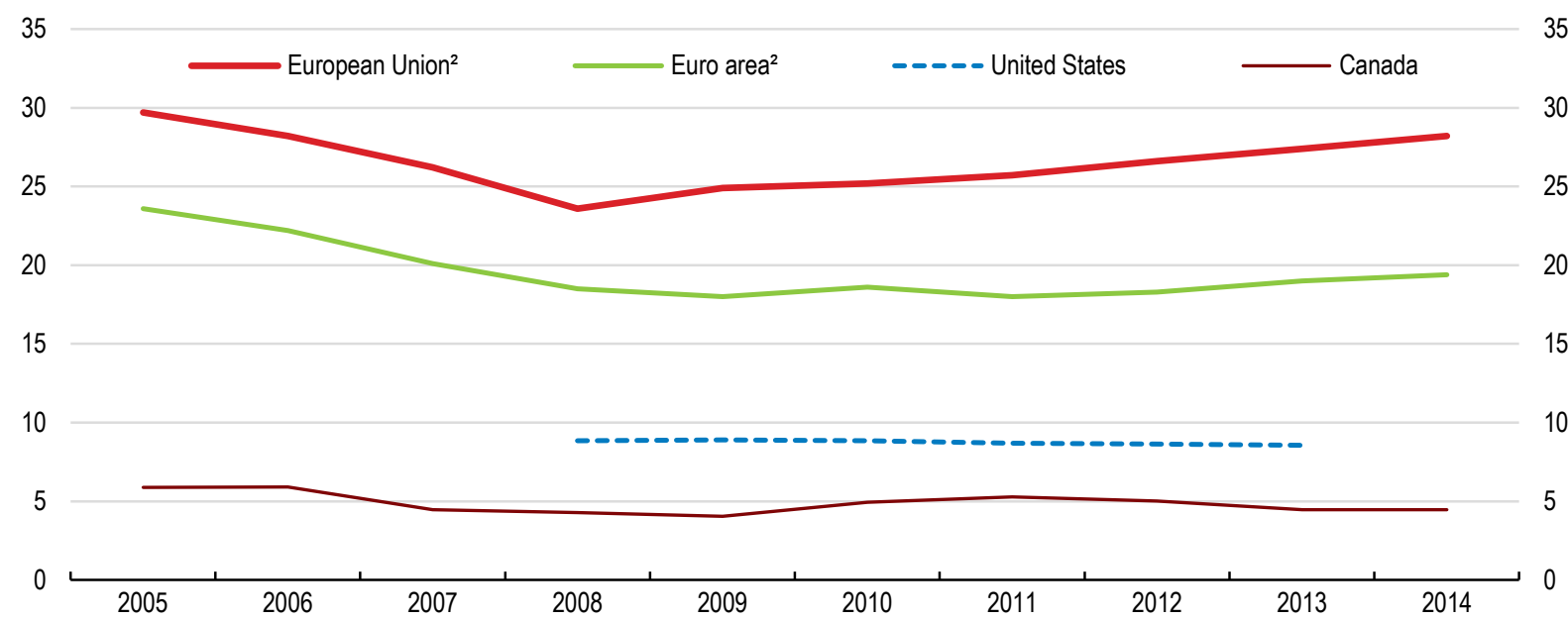

1. The coefficient of variation indicates the extent of variability relative to the mean of a series. Here the series shown are the price level index of household final consumption expenditure for the European Union and euro area, the implicit regional price deflator for the United States and the intercity index of price differentials of consumer goods and services for Canada.

2. European Union 28 countries and euro area 19 countries.

Source: Eurostat (2015), "Price convergence indicator", Eurostat Database; BEA (2015), "Real Personal Income for States and Metropolitan Areas, 2013", US Bureau of Economic Analysis; and Statistics Canada (2016), "Table 326-0015", CANSIM Database.

Figure 4. Product market regulation indicator

Total economy, index scale from 0 to 6 , from least to most restrictive ${ }^{1}$

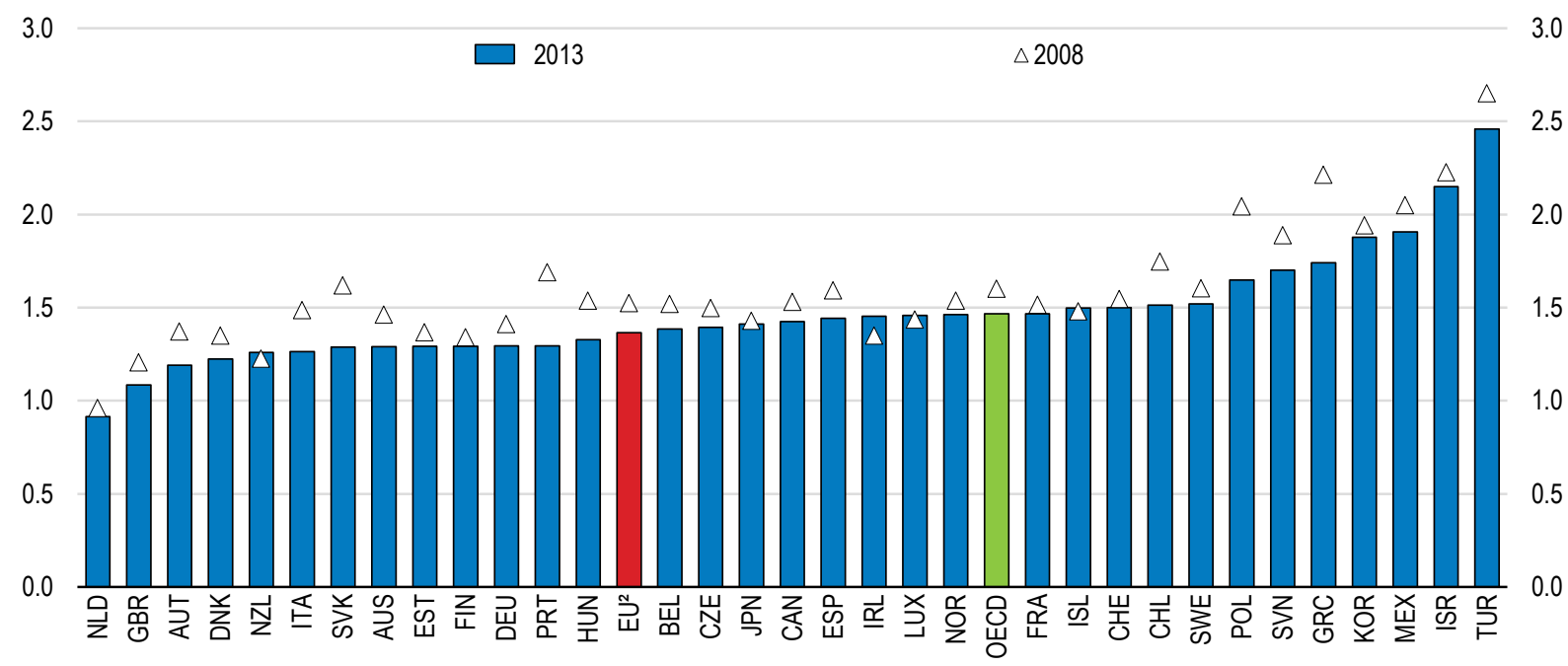

1. Data may no longer fully reflect the current situation in fast reforming countries. Data for 2013 is not available for the United States and it is excluded from the OECD aggregate in that year; the 2008 number for the United States is 1.11.

2. European Union member countries that are also members of the OECD (21 countries).

Source: OECD (2015), "Economy-wide regulation”, OECD Product Market Regulation Statistics (database). 
Figure 5. Regulation in professional services and network sectors

Product market regulation indicator, index scale from 0 to 6 , from least to most restrictive, ${ }^{1} 2013$
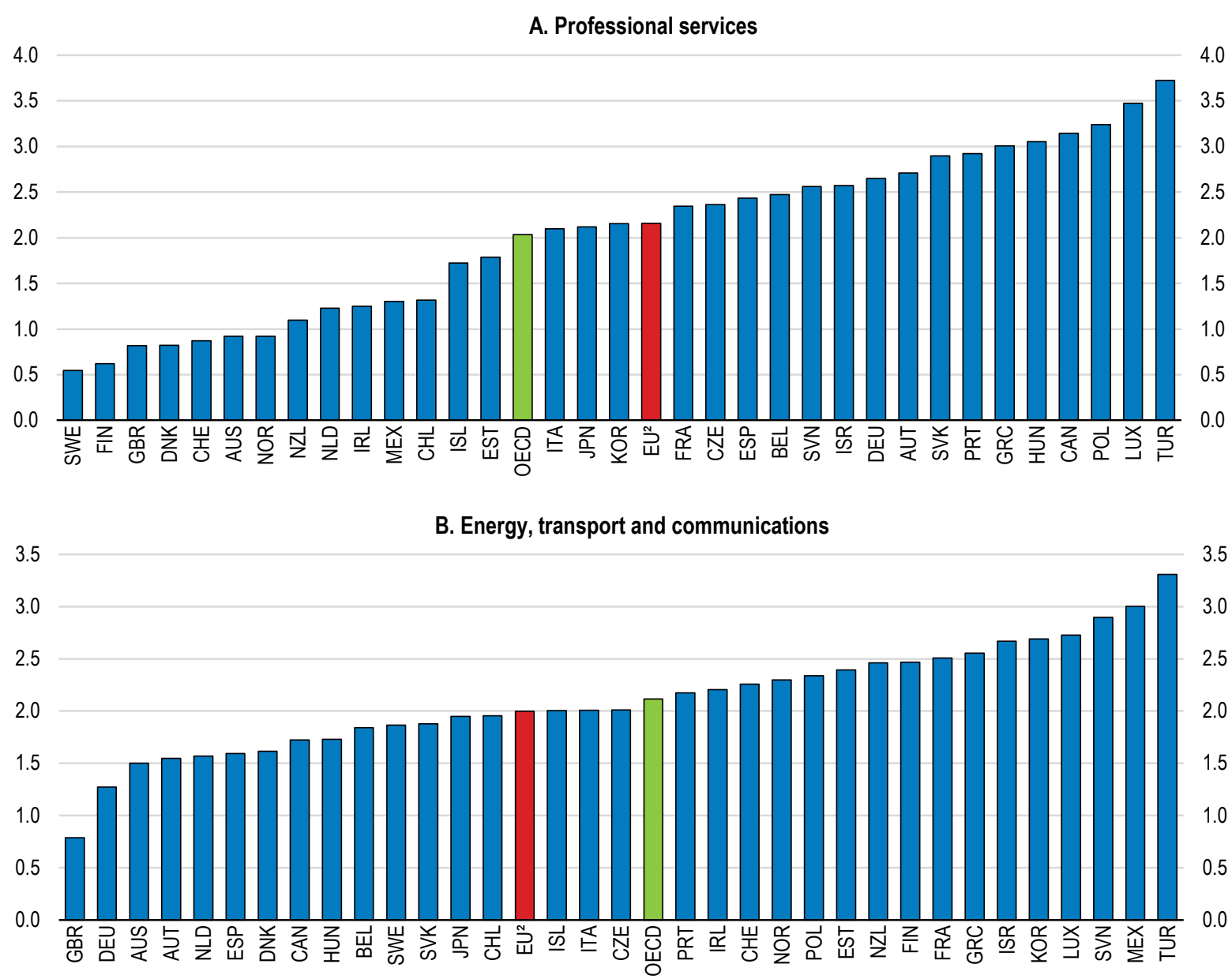

1. Data may no longer fully reflect the current situation in fast reforming countries. Data for 2013 is not available for the United States and it is excluded from the OECD aggregate; the corresponding 2008 numbers for the United States are 1.35 for professional services and 1.65 for energy, transport and communications.

2. European Union member countries that are also members of the OECD (21 countries).

Source: OECD (2015), "Sectoral regulation", OECD Product Market Regulation Statistics (database).

The mobility of capital and labour, two of the "fundamental freedoms" of the internal market (alongside the free movement of goods and services) would improve the economic performance in a way similar to trade in goods and services. Foreign markets can be served just as well through implantation of foreign firms as through imports, and firms investing in other EU countries or establishing themselves abroad are a key ingredient of the internal market. The financial and banking markets in the European Union remain fragmented, especially for small and medium-sized enterprises (SMEs). Borrowing costs have diverged across the euro area, especially for non-financial corporations, and despite narrowing in 2015, the dispersion has not yet returned to the level before the start of the sovereign debt crisis (Figure 6). In some countries interest rates continue to be held up by national sovereign debt positions and macroeconomic weakness (OECD, 2015a). Cross-border financial integration, although steadily improving, is unlikely to reach pre-crisis levels, as these were partly driven by unsustainable business models and excessive risk-taking (Figure 7). The picture is also mixed across individual financial markets, as the improvement in equity market integration is less clear than in money, bond and banking markets (ECB, 2015). 
Figure 6. Dispersion of nominal interest rates

Interest rates on loans to non-financial corporations, per cent ${ }^{1}$

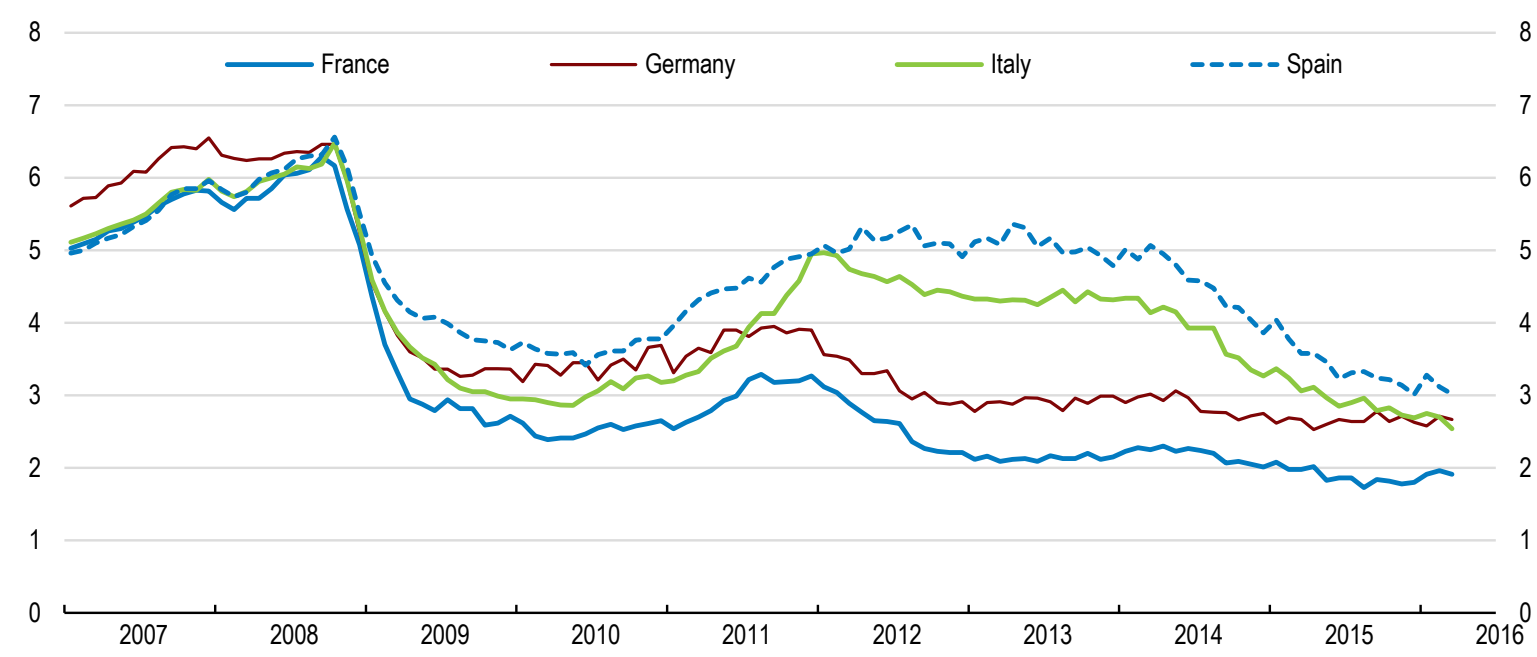

1. Loans of monetary and financial institutions to non-financial corporations up to and including EUR 1 million. Operations with an initial rate fixation period of less than one year for new business.

Source: ECB (2016), "Bank interest rates statistics", Statistical Data Warehouse, European Central Bank.

Figure 7. Cross-border positions of euro area monetary financial institutions

Per cent ${ }^{1}$
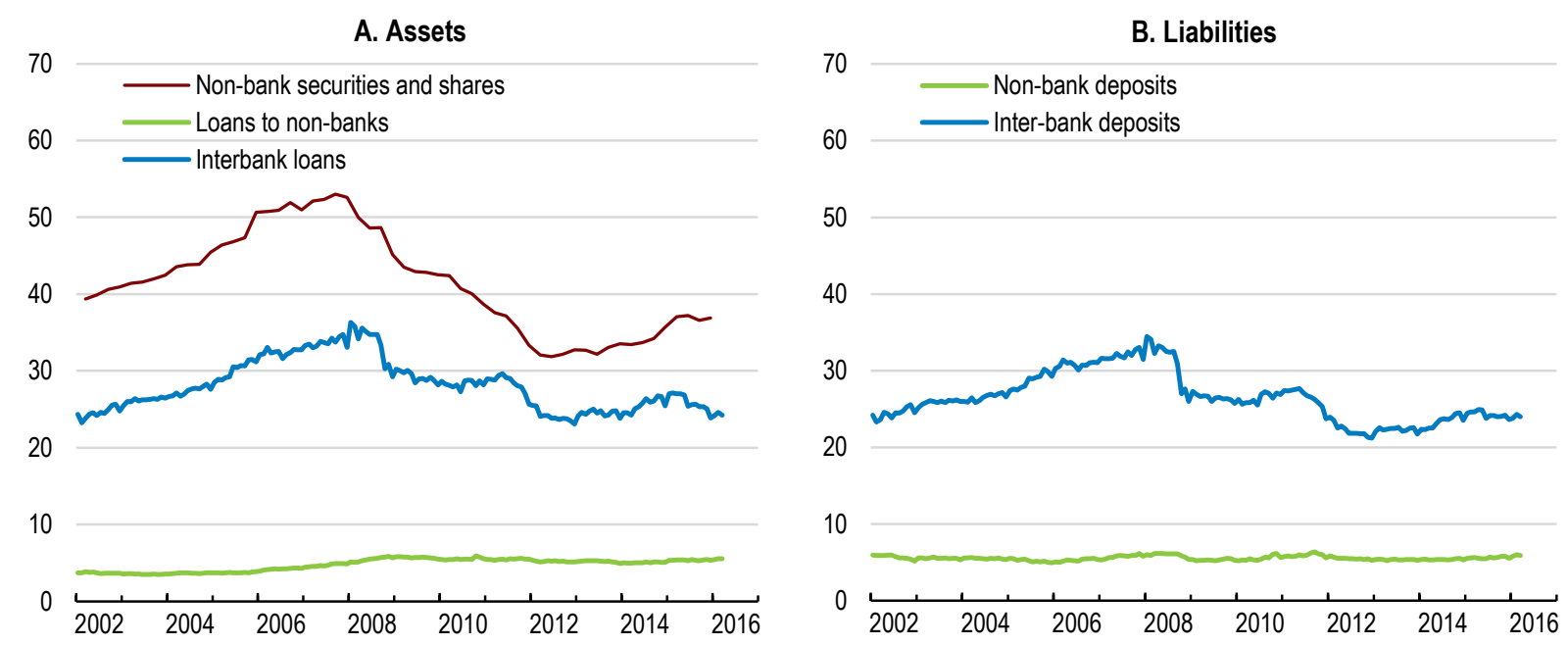

1. Cross-border activity as a percentage of the total provision of financial services in the euro area.

Source: ECB (2016), "MFI balance sheets: Monetary statistics", Statistical Data Warehouse, European Central Bank.

Labour mobility in the European Union and the euro area is still low compared to the United States, as documented by the evolution of unemployment rate variability in Europe and the United States (Figure 8). Although the 2008 financial crisis did trigger equilibrating labour flows in the European Union, most of the flows took place between the new and the old EU member states and in any case, the overall effect of these flows has been too small to help adjustment to regional labour market shocks (Chaloff et al., 2012). Some econometric studies using VAR models suggest that labour mobility response to cyclical changes in the euro area has been stronger than in the United States since the 2008 financial crisis (Dao et al., 2014; Jauer 
et al., 2014). The weaker US response may, however, be due to an increasing homogeneity of labour market conditions across US regions that could result in lower interstate migration.

Figure 8. Labour market fragmentation

Weighted standard deviation of unemployment rates, per cent

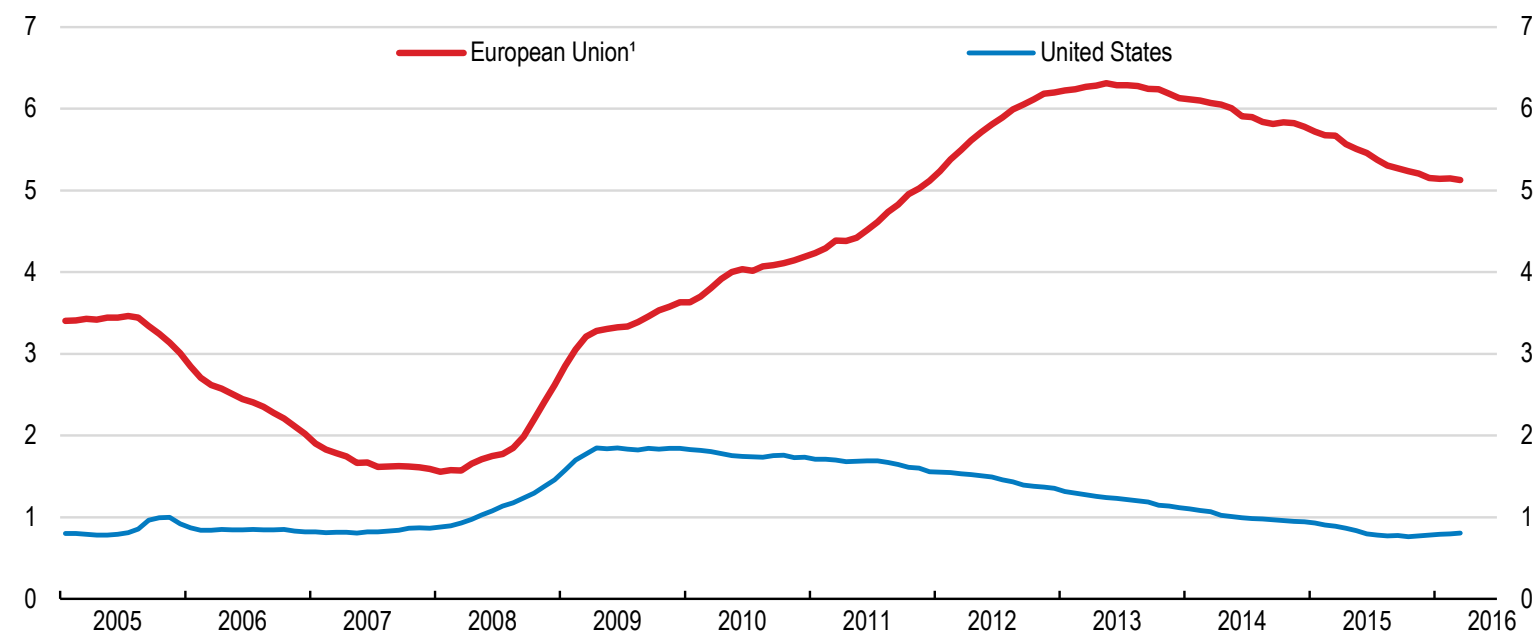

1. European Union 28 countries.

Source: Eurostat (2016), "Employment and unemployment (LFS)", Eurostat Database and BLS (2016), "Local Area Unemployment Statistics", US Bureau of Labour Statistics.

\section{What reforms at the current juncture?}

The economic recovery in Europe is modest and uneven, with asymmetries in cyclical conditions across countries. Weak public finances and monetary policy restricted by the zero-lower bound limit the support of the recovery through expansionary macroeconomic policies. Convergence of GDP per capita toward the United States level in the European Union has stalled in the 1990s and started deteriorating in the wake of the financial crisis (Figure 9), driven by both under-utilisation of labour and low labour productivity (Figure 10). Since monetary and fiscal policies remain constrained, and in any case limited in achieving objectives beyond the cyclical support, structural policies need to be geared toward boosting living standards and more income equality in the medium term, while supporting, or at least not damaging, the ongoing recovery.

Policies to enhance labour and capital mobility are especially relevant at the current juncture, as they provide both the support for cyclical stabilisation and the medium-term benefits, including improved allocation of resources leading to higher productivity. Labour and capital mobility enhancing policies facilitate equilibrating flows of labour and capital in the aftermath of asymmetric shocks, and thus act as an important shock-absorber and an implicit risk-sharing mechanism (de Grauwe, 2014). Capital mobility is also important for effective monetary policy transmission, since fragmented financial markets inhibit changes in the policy rate from translating into changes in financing costs for borrowers. In order to make the transmission channels of macroeconomic policies, such as credit provision, work again, other measures will be needed, including the reform of insolvency regimes (AFME, 2016). 
Figure 9. Gross domestic product per capita ${ }^{1}$

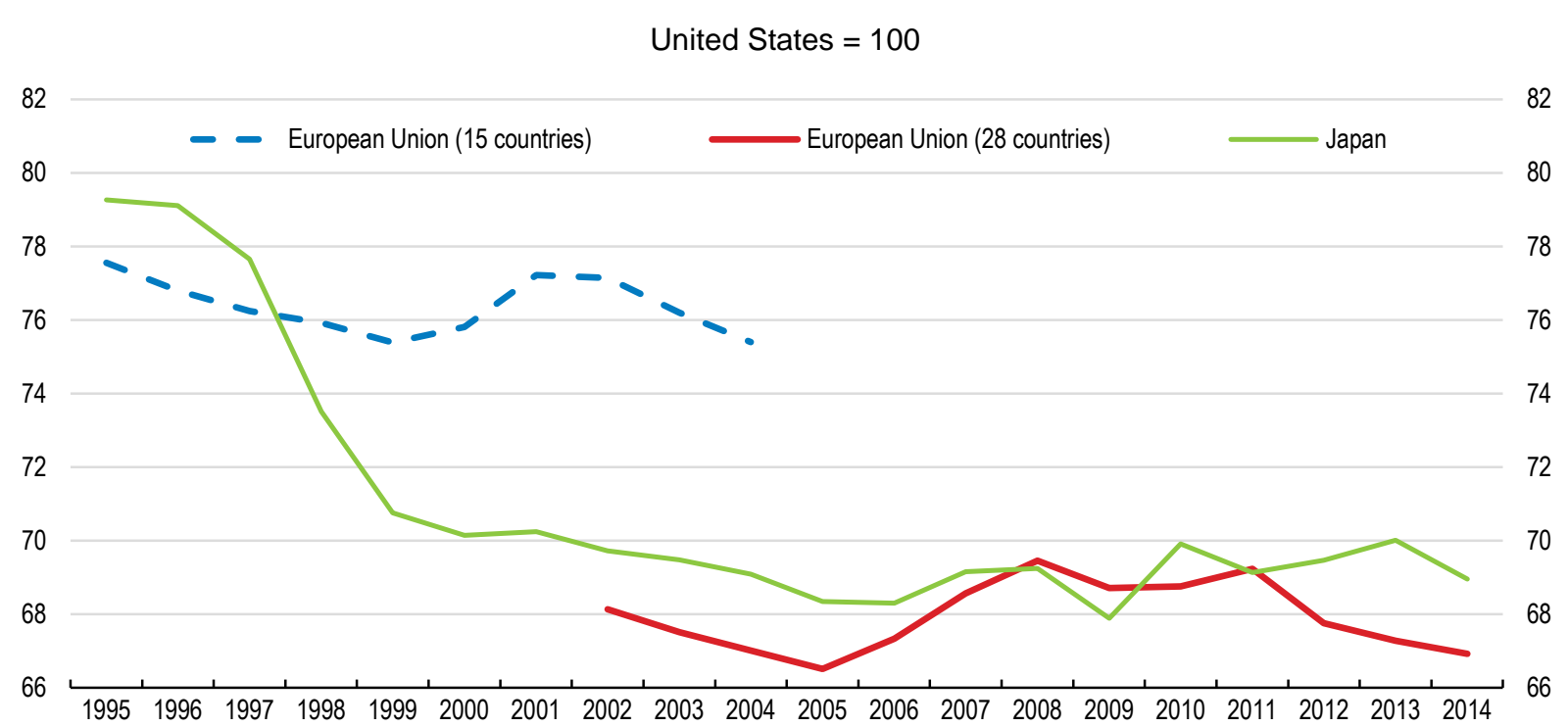

1. GDP at constant prices and constant purchasing power parities.

Source: OECD (2016), "Aggregate National Accounts, SNA 2008: Gross domestic product", OECD National Accounts Statistics (database).

Figure 10. Labour utilisation and productivity

Percentage difference compared with the United States, $2014^{1}$

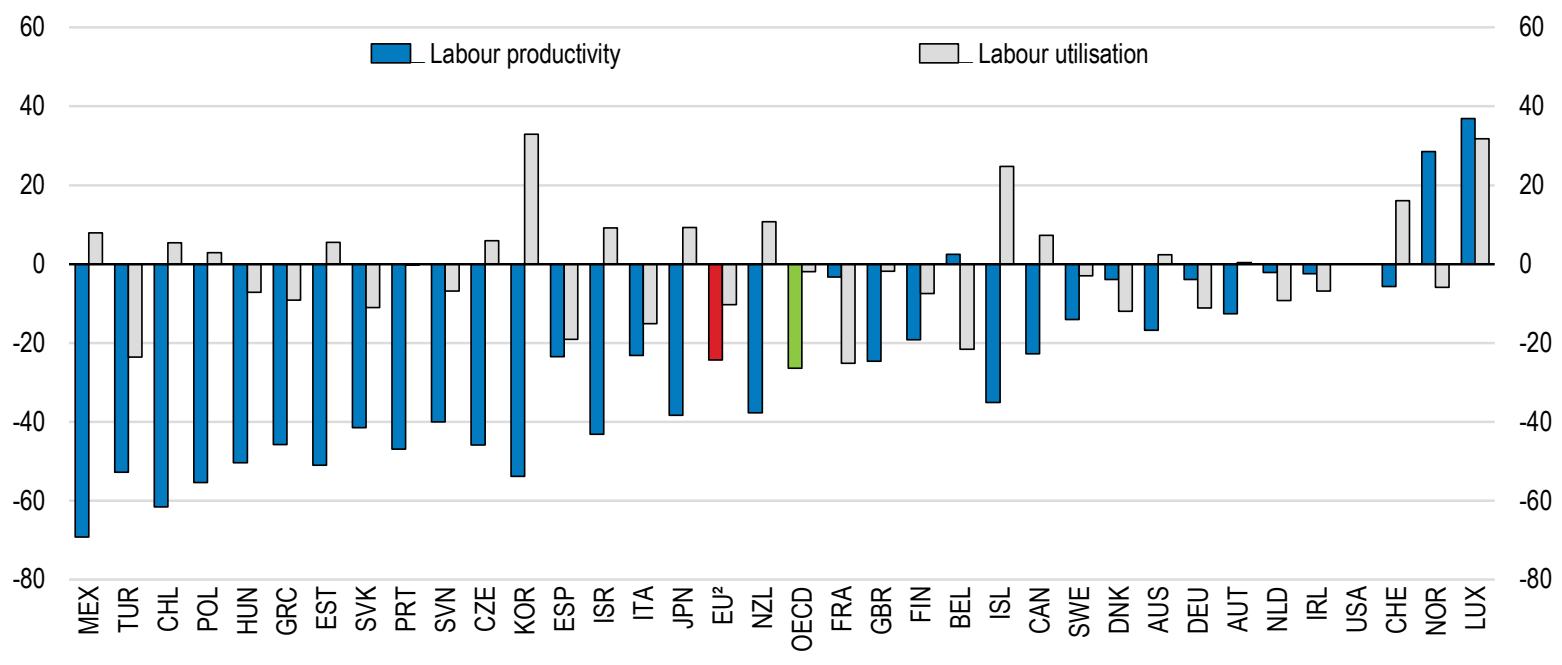

1. Labour productivity is measured by GDP per hour worked and labour utilisation by hours worked per head of population. Data are sorted in order of GDP per capita percentage difference with the United States.

2. European Union 28 countries.

Source: OECD (2016), "GDP per capita and productivity levels", OECD Productivity Statistics (database).

The medium-term improvements to productivity and potential output will require the continuation of substantial structural reforms. The Going for Growth responsiveness indicator shows a slowdown in reforms in many OECD countries (Figure11). The slowdown is most pronounced in countries that exhibited highest levels of reform responsiveness between 2009 and 2012, including the euro area countries with programmes of financial support. 


\section{Figure 11. The pace of reforms has slowed}

Reform responsiveness rate indicator ${ }^{1}$

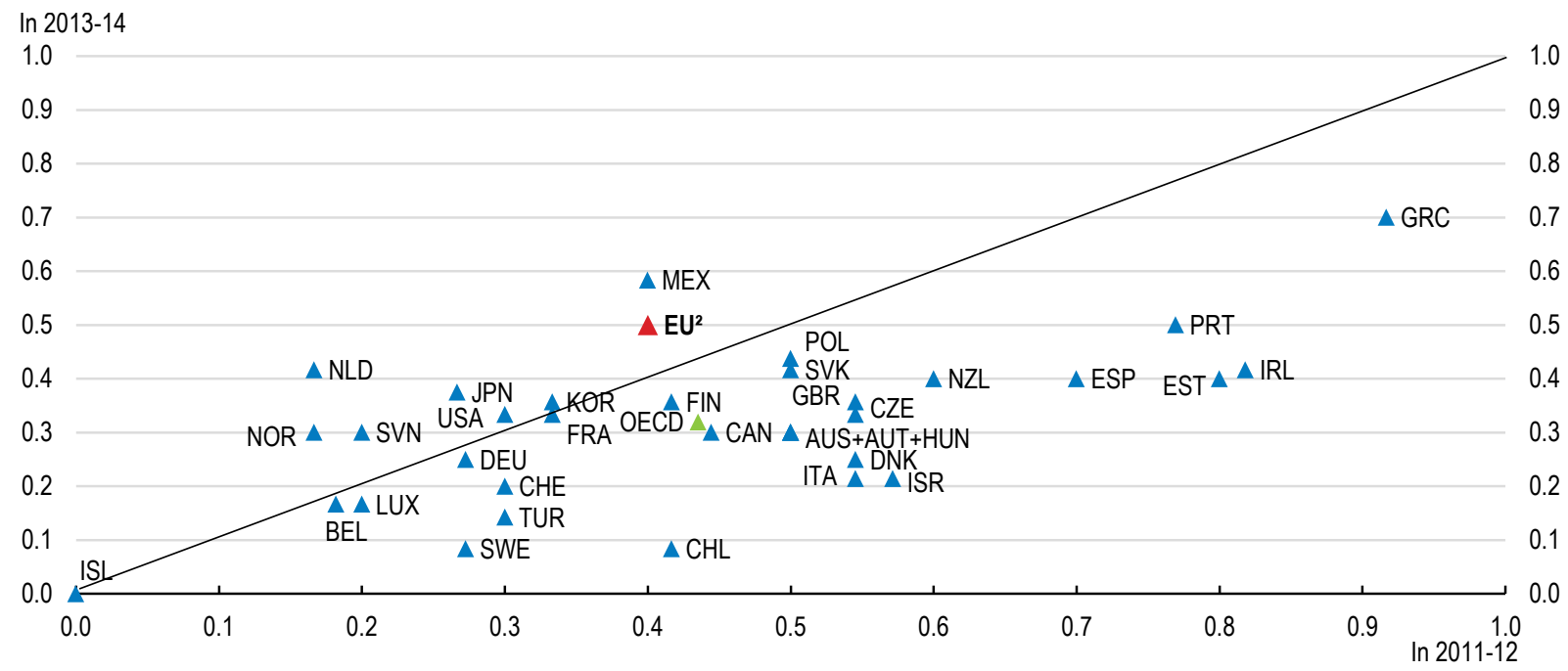

1. The index of structural reform is measured by the change in the composite indicator which is based on a scoring system where recommendations set in the previous issue of Going for Growth take a value of one if "significant" action is taken and zero if not. An action is considered as "significant" if the associated reform addresses the underlying policy recommendation and if it is actually legislated; announced reforms are not taken into account.

2. European Union member countries that are also members of the OECD (21 countries).

Source: OECD (2015), Economic Policy Reforms 2015: Going for Growth.

The growing literature on the sequencing of reforms suggests that when the economy is weak transitory costs and distributional impacts of reforms tend to favour product market reforms over labour market reforms (Caldera Sánchez et al., 2016). Product market reforms have potentially large payoffs, including higher real wages, which may facilitate the subsequent labour market reform (Blanchard and Giavazzi, 2003). Pro-competition reforms in product markets are also needed to ensure that recent labour market reforms implemented in the programme countries result in job creation in sectors where there is pent-up demand and in lower consumer prices rather than higher profits (OECD, 2015b).

Competition-enhancing product market reforms foster innovation and productivity (Aghion et al., 2009), often through investment in knowledge-based capital, thus reducing the demand for low-skill, routine jobs in favour of high-skilled workers (Bresnahan et al., 2002). This effect can be contained if complemented with labour mobility-enhancing and job creating policies (OECD, 2015b; Causa et al. 2015). Empirical OECD studies show that many structural policies, with the possible exception of innovation policies and skill-biased technological progress, have little or no impact on income inequality among households (Braconier and Ruiz-Valenzuela, 2014). The need to compensate, at least partly, some of those who lose out from structural reforms, may, however, add to the cost of reforms in the short and medium term.

The next section discusses labour and capital mobility-enhancing policies as tools in support of the ongoing recovery; the subsequent two sections examine, respectively, horizontal and sector-specific policies for boosting potential growth in the European Union.

\section{Structural reforms to facilitate the recovery}

Both labour and capital mobility increase resilience in the face of idiosyncratic shocks. Cross-border financial flows play an important role both as a buffer against shocks and a precondition of effective monetary policy transmission. Financial intermediation in Europe remains predominantly bank-based. As a 
result of this dependence, the level of risk-sharing compared to federations like the United States, Canada or Germany tends to be considerably lower and biased towards credit, rather than capital flows (IMF, 2013). Moreover, the risk-sharing through bank credit channel tends to break down in periods of crisis, making the adjustment in the euro area a costly and protracted process (Furceri and Zdzienicka, 2013).

Labour mobility can better match demand and supply in the internal market, and in doing so can reduce qualification mismatches apparent in some EU countries and help people return to work. Crossborder movement of workers also reduces unemployment in the country of origin and may even help rebalancing through remittance flows. In addition to increasing resistance to asymmetric shocks (Ahrend et al., 2011), the advantages of labour mobility in a monetary union at the zero-lower bound and with limited fiscal space may even extend to common shocks (Erceg and Lindé, 2010). In addition to its role in enabling better and more uniform transmission of monetary policy, labour mobility can also improve the accumulation of human capital in the medium term, as mobile workers acquire better skills and contribute to the diffusion of best working practices.

\section{Capital mobility-enhancing policies}

Capital markets in the European Union are less integrated than in the United States. Moreover, the reliance of EU firms on bank financing is much higher than in the United States (Figure 12). A functioning capital markets union (CMU) is an important complement to the banking union that will improve the balance of financial intermediation in Europe, reduce the reliance of non-financial companies on banks and by enhancing cross-border risk-sharing help weaken the bank-sovereign nexus (Cœuré, 2015). Removing or decreasing the major obstacles to capital markets integration will also increase resilience and encourage banks to reach an optimal size relative to the European market.

Figure 12. Bank and capital market financing of enterprises

Outstanding loans ${ }^{1}$ and bonds of non-financial corporations as a percentage of GDP, period average

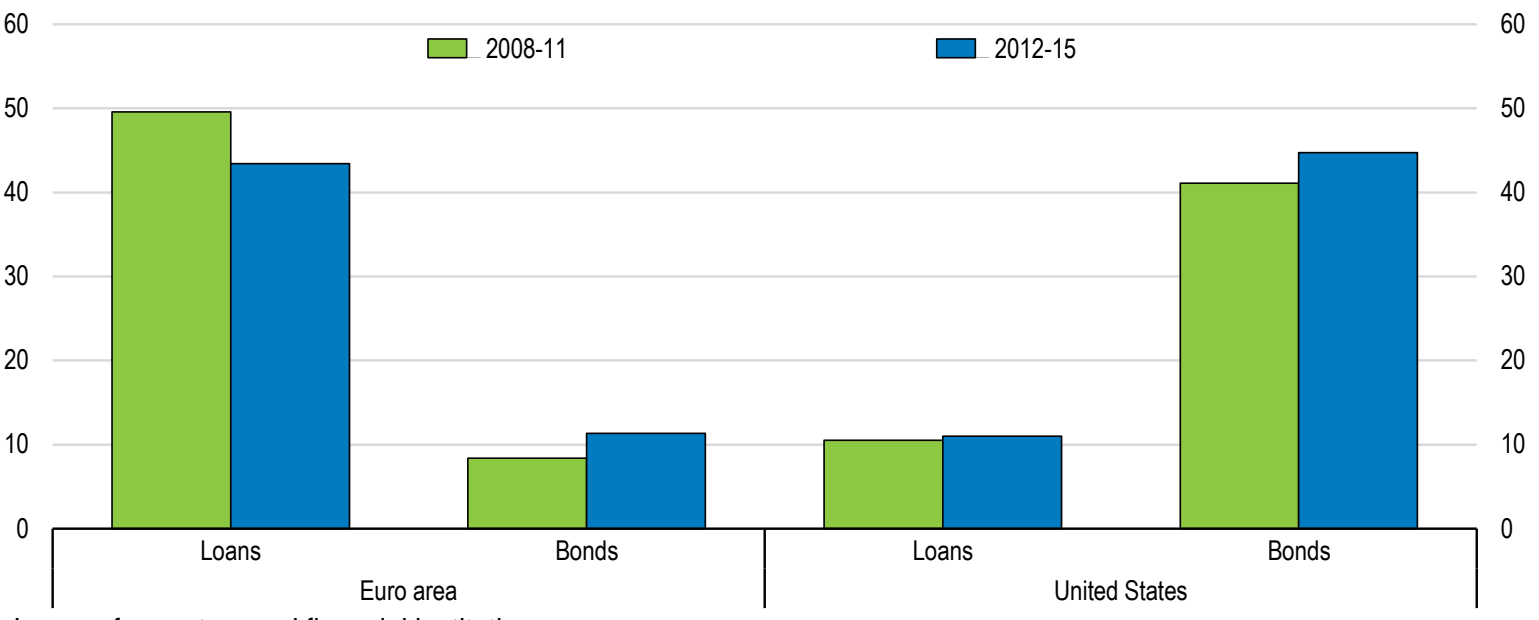

1. Loans of monetary and financial institutions.

Source: Eurostat, European Central Bank, US Bureau of Economic Analysis, Board of Governors of the Federal Reserve System, and Securities Industry and Financial Markets Association.

The overarching objective of the CMU is to enhance both the domestic and cross-border supply of capital to firms, especially SMEs, mainly through lowering regulatory barriers, widening of investor base and investment choices, and deepening financial integration. The CMU package consists of both legislative proposals and non-legislative initiatives. Proposals that have already been operationalised, such as making prospectuses more accessible for investors, revising the risk calibrations on infrastructure investments by 
banks and insurers, and simple, transparent and standardised securitisation are welcome and could help creating positive momentum for the forthcoming parts of the package.

The reduction of regulatory heterogeneity can bring short-term improvements. Stock exchange groups that operate in more than one EU country (such as Euronext or Nasdaq Nordic) are currently subject to both harmonised rules, for example under the Markets in Financial Instruments directive, and nonharmonised local rules that only apply in individual local markets. Harmonising the local rules, such as local admission and trading rules, could reduce operational costs and spur another wave of stock exchange consolidation improving liquidity and providing more efficient pricing that may further lower the financing costs for market participants (Kaya, 2015). Barriers resulting from complex and fragmented trading and post-trading infrastructure in the European Union, reflecting the legacies of past national systems as described in the Giovannini reports, should be reduced or eliminated (Véron and Wolff, 2015).

Under-pricing of risk coupled with potentially inadequate regulation in the run-up to the financial crisis tarnished the reputation of securitisation. There was a sharp contraction in issuance, although this was mitigated in Europe by the eligibility of some products, including asset-backed securities and covered bonds, for the European Central Bank (ECB) refinancing operations and asset-purchase programmes (Figure 13). The rebound in securitisation is important for bank lending and for financing of SMEs unlikely to tap the stock and bond markets. The CMU could help reviving the securitisation markets by easing the regulatory treatment that discourages institutional investors. The rules for simple, transparent and standardised securitisation may help SME lending, especially after the current period of very low policy interest rates comes to an end.

Figure 13. Asset-backed securities used in refinancing operations with the ECB

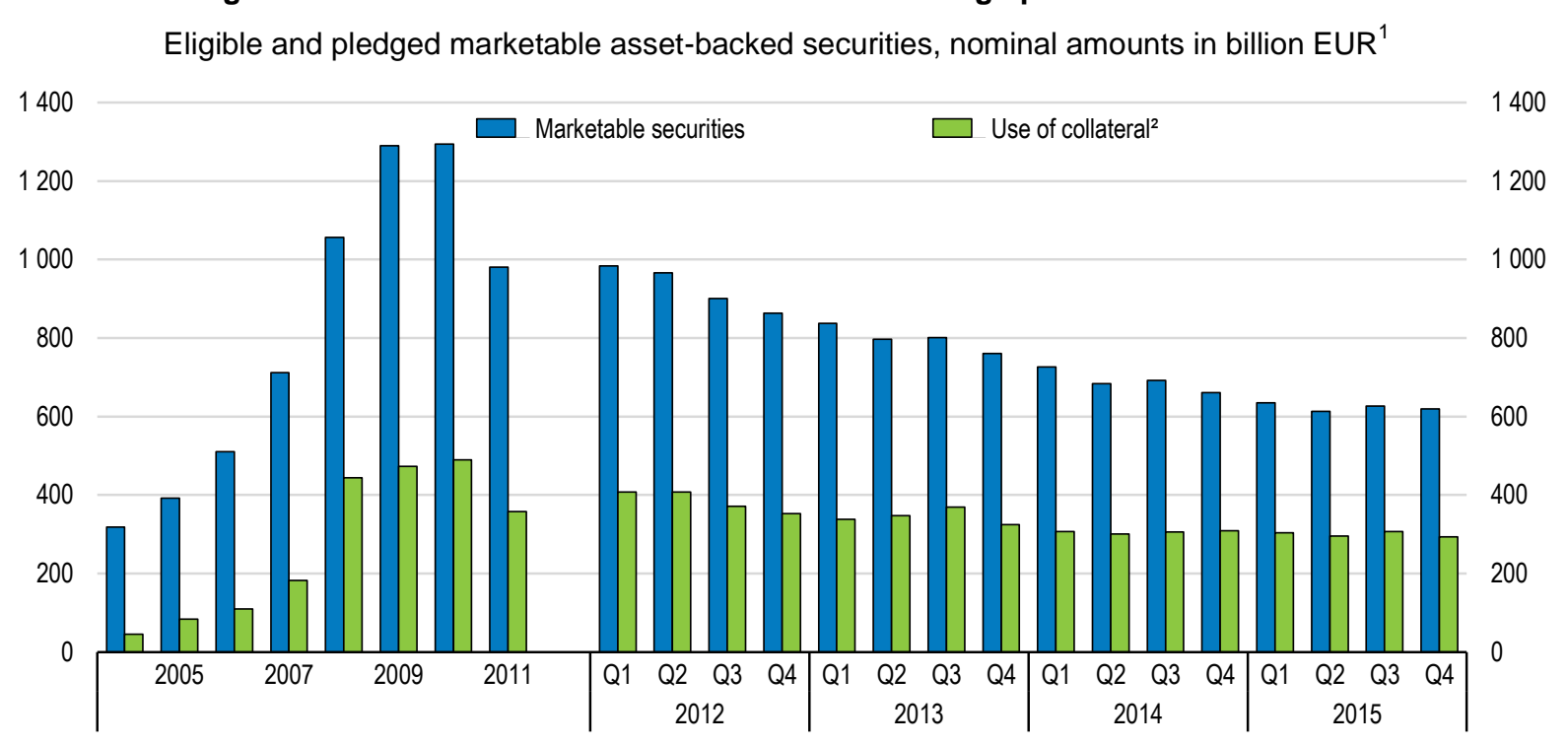

1. Averages of end of month data over each time period shown.

2. After valuation and haircuts.

Source: ECB (2016), "Eurosystem Collateral Data”, European Central Bank, www.ecb.europa.eu/paym/coll/html/index.en.html.

The investor base could be expanded by introducing standardised pan-European financial products and investment vehicles, including venture capital fund-of-funds and multi-country funds. Supporting the development of the most effective information system that connects SMEs with a range of funding sources can be an effective tool to tackle the asymmetric information problem associated with SME financing, for example through transparent and standardised data warehouses that collect and share credit information on 
smaller firms with all market participants, such as already used by the Banque de France for French companies or AnaCredit recently constructed by the ECB (OECD, 2015a).

The potential success of the CMU, beyond important and useful fine-tuning of the existing rules, will require addressing the legal and regulatory barriers in the EU capital markets, including those resulting from company, securities and insolvency laws. Barriers also exist in other areas under competence of national states, such as taxation, both of debt versus equity and residents versus non-residents. The bias in tax treatment of debt and equity should be reduced. Some member states lower the debt-equity bias through an allowance for corporate equity, which requires a careful design to prevent abuse (Zangari, 2014). Limitations on the deduction of interest payments, in line with the recommendations of the OECD/G20 Base Erosion and Profit Shifting Action Plan, provide another way of reducing the debt-equity bias, as does the integration of capital income taxes at the corporate and personal level.

The absence of an EU-wide insolvency regime discourages cross-border investment and timely restructuring and complicates the resolution of non-performing loans that absorb large volumes of regulatory capital and hamper new bank lending (IMF, 2015). National insolvency laws and practices vary across multiple dimensions, including the applicable triggers of insolvency, ranking of creditors, filing and verification of claims and liability of management and shareholders. A more efficient European insolvency regime might require, for example, a consistent framework for valuation and resolution of valuation disputes as well as sufficient time for the debtor to reach agreement with creditors and an increased involvement of creditors in insolvency proceedings, possibly introduced through a harmonised introduction of minimum standards into national systems of all member states. Furthermore, consistency in the application of insolvency laws and procedures by the courts and practitioners should also be supported at the EU level (AFME, 2016).

As harmonisation by the means of a single rulebook alone does not seem to be sufficient for effective implementation and consistent enforcement of the CMU rules and standards (Cœuré, 2015), it will also require an increased focus by the European Securities and Markets Authority on achieving convergence of supervisory outcomes. The links within the EU regulatory network, including the co-operation with national authorities and supervisory convergence with the Single Supervisory Mechanism (and vice versa), should be strengthened further. Implementation and enforcement of the single rulebook may profit from co-operation on issues common to banking and securities market supervision. Such co-operation may strengthen the integration of capital markets, without harming the peer-review model of the national supervisors (Valiante, 2015; Véron and Wolff, 2015).

\section{Labour mobility-enhancing policies}

Labour market mobility in the European Union is increasing (Figure 14), as confirmed by preliminary OECD data on free movement in 2014 (OECD, 2015c), reflecting, among other things, posted workers, intra-company transferees and seasonal migration from the Central and Eastern European member states. The overall level of labour mobility in the European Union, however, remains low in comparison with the United States and other federal countries, which reflects a number of non-policy factors, such as linguistic and cultural differences, as well as policy barriers, including the lack of harmonisation of social security systems and of professional qualifications, and other legal and administrative barriers (OECD, 2014a). 
Figure 14. Stock of migrant population within the European Union

Population that are citizens of another EU28 country, as a percentage of total population

3.5

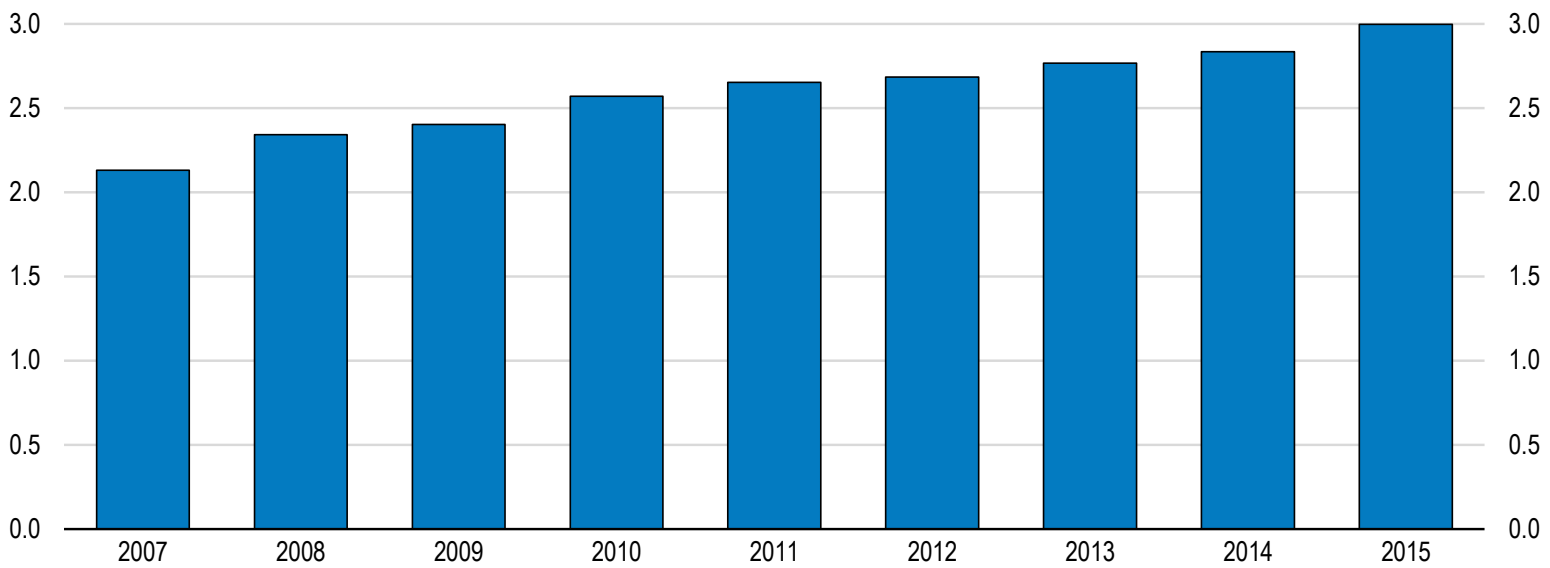

Source: Eurostat (2015), "Population on 1 January by five year age group, sex and citizenship", Eurostat Database.

There is some evidence of equilibrating migration flows in the wake of the financial crisis (Jauer et al., 2014), as the net inflows to crisis-hit countries such as Spain and Ireland reversed into net outflows and net immigration to countries like Germany and Austria, characterised by low unemployment rates, rose (Figure 15). At least in some labour market segments, such as health personnel, the intra-EU mobility seemed to have a balancing effect by reducing the risks of under-employment and supporting the living standards in countries hit by the crisis; moreover, this adjustment has been facilitated by the EU provisions for recognising professional qualifications (OECD, 2015c).

Figure 15. Immigration and emigration flows between EU countries ${ }^{1}$

Per thousand inhabitants

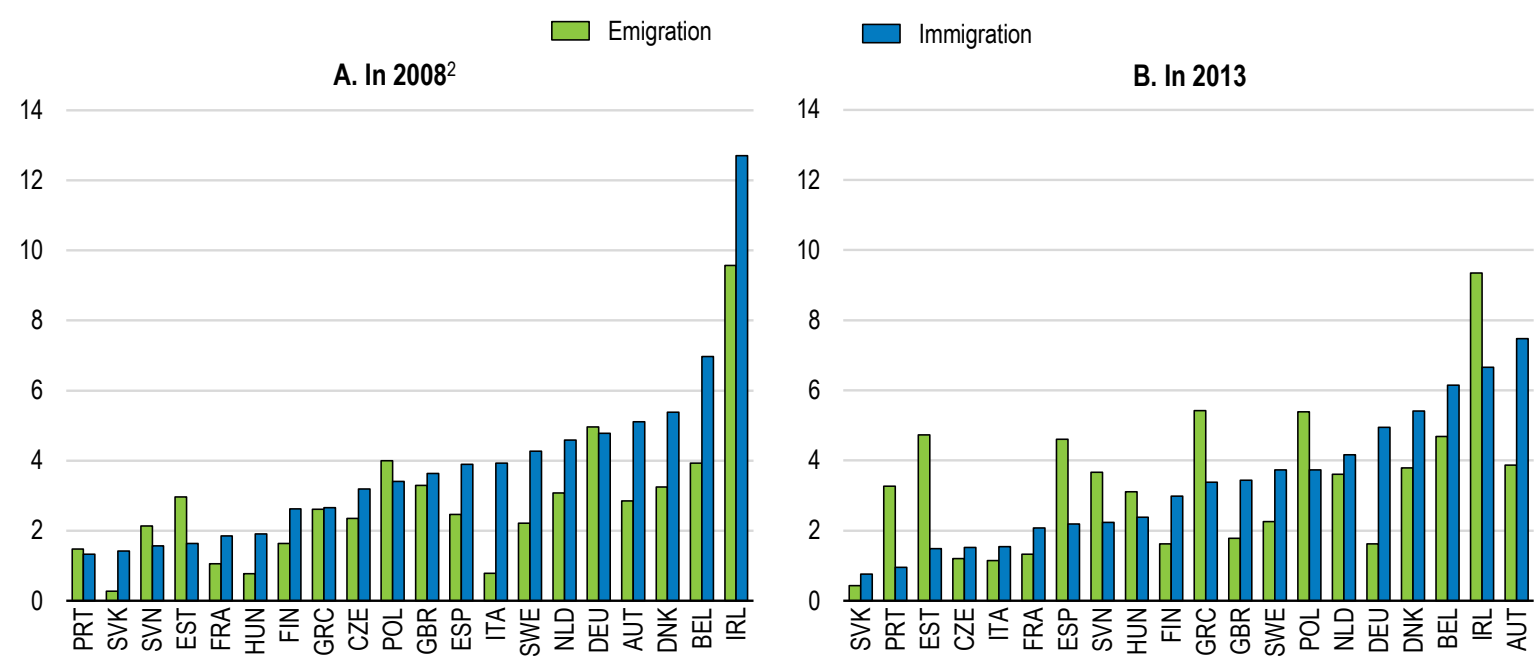

1. "Immigration" covers persons establishing their usual residence in an EU country for at least 12 months having previously been usually resident in another EU country; "Emigration" covers persons having previously been usually resident in an EU country who cease to have their usual residence in that country for at least 12 months. Data for EU27 countries in 2008 and EU28 countries in 2013. International migration flow data are based mainly on administrative sources or national surveys and differences in definitions and practices can affect the comparability of data across countries.

2.2009 for Poland and 2010 for Belgium.

Source: Eurostat (2016), “Demography and migration”, Eurostat Database. 
Since language skills are not firm-specific and given the significant positive externalities for the society from ensuring that the host-country language is spoken well by immigrants, there is a strong case for public funding for language training. Indeed, an important factor that keeps the intra-EU labour mobility low is the lack of proficiency in the language of potential destination countries, an impediment cited by more than a half of respondents in the special Eurobarometer survey on geographical and labour market mobility (European Commission, 2010). Publicly funded language courses are available to newcomers in only 14 member states. As they are usually available as part of integration policies for thirdcountry nationals, they are largely disconnected from policies supporting labour mobility and are not tailored to EU workers (Eurofound, 2015). Few OECD countries provide publicly-funded language training for labour migrants, even though in some OECD countries language knowledge is a pre-condition for labour migrants for obtaining a work permit (OECD, 2013a).

Better foreign language proficiency among students would pave the way for higher labour mobility upon completion of studies. The Erasmus programme facilitates foreign language learning by encouraging cross-border exchanges and contains useful elements, including provisions for access to loans for a Master's programme in another country. However, the programme should be extended to include more students, as less than 5\% of graduates in 2012 and 2013 profited from it (European Commission, 2015a).

Recognition of professional qualifications has been facilitated by the amended Directive 2005/36/EC that updates training requirements for a number of professions and opens the way to wider automatic recognition by introducing training frameworks based on common sets of knowledge and competences (EUA, 2014). Introduction of the European Professional Card, an electronic procedure for professional qualification recognition that applies the silence-is-consent approach in some of its aspects, will help reduce administrative burdens and speed up procedures associated with recognition of professional qualifications. Only some 5\% of applications for recognition of qualification have been rejected EU-wide between 2010 and 2014, with considerable differences in rejection rates across the member states (Figure 16). Even if the overall success rate is high, slow procedures can still constitute a barrier to mobility, so the European Union should monitor improvements and best practice and consider partial recognition complemented by a shortened additional education (CEPS, 2014) and application of a silenceis-consent principle in areas without major safety or environmental concerns. Regulatory barriers arising from diverging legal forms, shareholding requirements and other organisational requirements in accounting, architecture, civil engineering and construction companies should also be reviewed and reduced.

Figure 16. Recognition of professional qualifications

By country where the qualification was obtained, 2010-15 ${ }^{1}$
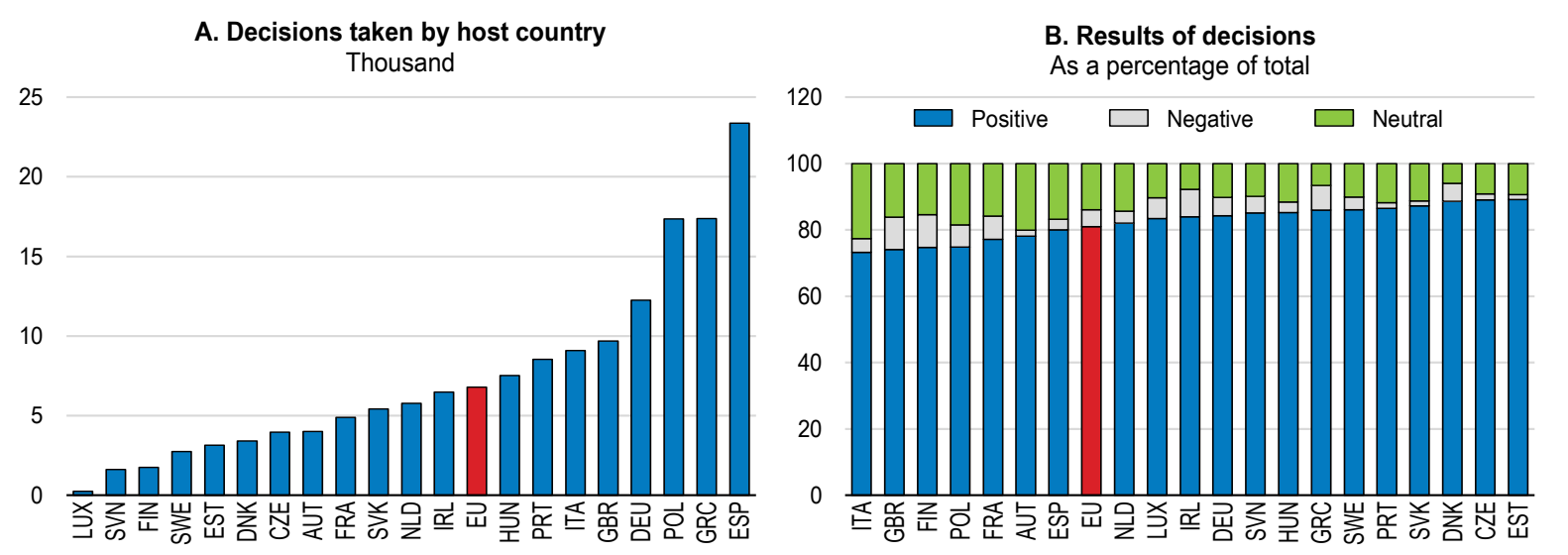

1. Within European Union applications only. The European Union aggregate is an unweighted average of data for the 28 member countries.

Source: European Commission (2016), Regulated Professions Database, http://ec.europa.eu/growth/tools-databases/regprof (accessed on 11 May). 
Labour mobility also increases with the portability of supplementary pension rights, as the risk of losing acquired pension rights and long vesting periods can be a strong disincentive to taking up work abroad (CEPS, 2014). Directive 2014/50/EU adopted in 2014 improves the situation by limiting the vesting and waiting periods to three years. Portability of other social benefits, such as unemployment, family and health care benefits is also important for labour mobility. The empirical analysis of EU data for various types of benefits suggests that less complicated portability may increase the propensity to move abroad for professional reasons (d'Addio and Cavalleri, 2015).

Labour mobility is also dampened by the possibility of double taxation issues related to pensions as well as incomes of cross-border commuters who live in one EU country but work in another, of workers posted abroad and of people living and looking for work abroad who exported their unemployment benefits to another country. Supplementary pensions were made more portable by adoption of a 2014 directive, but other situations are mostly covered by bilateral tax agreements and would profit from broader coordination across EU countries (OECD, 2014a).

Public employment services in the member states also have an important role in promoting the crossborder job matching. The new rules for the European employment services network enhance the labour mobility through extended coverage and participation. The online portal will provide information about most of publicly available vacancies as well as specific support to cross-border workers from EU countries.

There are also obstacles to the mobility of non-EU nationals, which put EU countries at a disadvantage in the global competition for skills and talent. Non-EU nationals may reside in a second EU country for work and training purposes after becoming long-term residents (after at least five years of legal and continuous residence in a first member state) but the Long-term Residents directive is not implemented in a comparable way in all member states (European Commission, 2011), and Denmark, Ireland and the United Kingdom are exempted from the application of the directive. The shares of awarded long-term residency permits vary considerably across countries, reflecting in part additional conditions applied by the member states (Figure 17). The Blue Card scheme allowing high-skilled non-EU citizens to work and live in the European Union should be modernised and its eligibility requirements and procedures simplified, in order to make it more attractive relative to existing schemes (Chaloff, 2016). Transparent EU-wide minimum salary levels for eligibility could help to ensure that the card issued to certain professions in one EU country is valid for all member states (CEPS, 2014). 
Figure 17. Long-term residency permits

Number of persons with long-term residence status per 10000 inhabitants, 2012-14 ${ }^{1}$

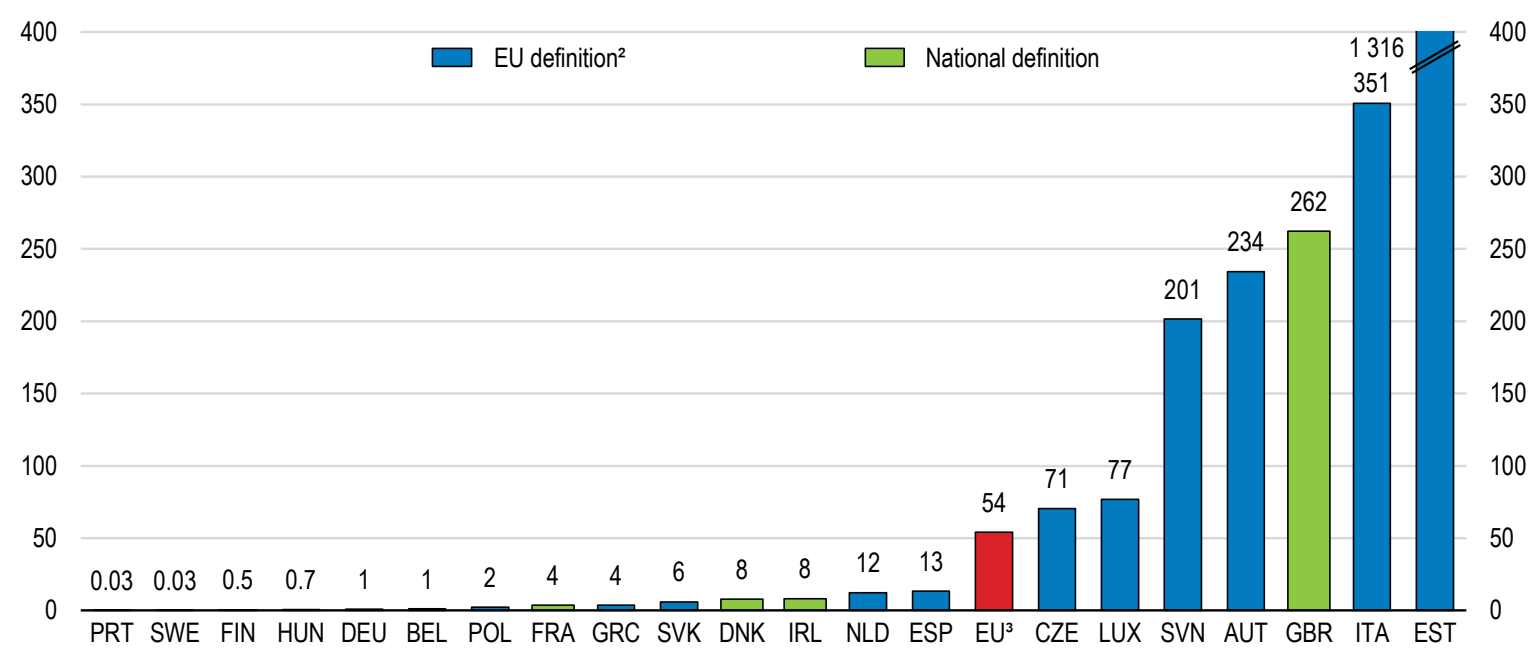

1. Due to the recent implementation of the Residence Permits Data Collection, some methodological and administrative differences still exist between the Member States. 2012-13 for the Netherlands.

2. EU long-term resident status as defined in Council Directive 2003/109/EC (not adopted by Denmark, Ireland and the United Kingdom). The main criteria are five years of legal and continuous residence, stable and regular resources (no social assistance) and sickness insurance. In addition the presence of the person should not constitute a threat to public policy or security.

3. European Union 28 countries.

Source: Eurostat (2016), “Asylum and managed migration" and "Demography and migration”, Eurostat Database.

\section{Horizontal policies to boost potential living standards}

Improvements in the quality of regulation can raise incomes, and therefore well-being, by providing simple and coherent rules that minimise costs and market distortions, promote innovation and are implemented in a fair and transparent manner (OECD, 2015d). Excessive regulation and regulatory heterogeneity across countries also lowers potential growth, because it leads to sub-optimal trade and investment flows (Fournier et al., 2015; Fournier, 2015). Similar effects of regulatory heterogeneity on bilateral intra-EU trade and intra-EU foreign direct investment flows in service sectors were found by Nordås and Kox (2009).

\section{Better Regulation}

The EU effort to improve the quality of regulation and lighten the regulatory burden spans several initiatives, which in many cases have not been fully implemented at the national level. The Better Regulation package proposes improvements in developing, adoption, implementation and expost evaluation of EU legislation (European Commission, 2015b). The Commission has emphasised evidencebased policy-making and it indeed seems useful to have an impact assessment of final legislation that can also serve as an input for the following evaluation, completing the policy cycle (Renda, 2015). In April 2016 a new inter-institutional agreement on better law-making was reached between the Commission, the Parliament and the Council. This agreement covers several aspects of law-making including transparency, simplification, evaluation and the feasibility of establishing objectives for administrative burden reduction in key sectors. It also sets out a general commitment to assess impacts of Commission proposals and of significant amendments by co-legislators, where considered relevant. However, an agreement on subjecting the Parliament's and the Council's legislation to impact assessment (similar to that applied to the Commission), already proposed by the Commission in 2003 and 2005 was not reached. 
The Commission is obliged to conduct public consultations as an essential element of its policy preparation and review. The Better Regulation package further strengthens the commitment to consult throughout the policy cycle, including the establishment of a consultation strategy for each initiative before the work starts, obligatory 12 week public consultations for all initiatives subject to an impact assessment as well as feedback opportunity for citizens and stakeholders on various documents, including the draft legal acts (OECD, 2015d). While broadly in line with the existing best practice, the proposal does not provide enough detail on where the resources for new impact assessments will come from, or enough guidance on the balance between regulatory costs on one hand and the quality of resulting regulation on the other. More detail would also be welcome on how the analytical criteria for regulatory impact assessments align with the Europe 2020 indicators that represent EU's vision of smart, sustainable and inclusive growth.

In order to improve the law-making process, the European Commission proposes turning the existing Regulatory Fitness and Performance Programme (REFIT) for simplification and reduction of regulatory burdens into a permanent platform for dialogue with member states and stakeholders (European Commission, 2015b). The Impact Assessment Board was replaced by a new body, the Regulatory Scrutiny Board, which includes external experts and scrutinises the quality of impact assessments, evaluations and fitness-checks carried out by the Commission. The involvement of independent experts is welcome, although the Regulatory Scrutiny Board will not have the power to block the Commission's proposals. The proposed structure, including the chairperson of the Regulatory Scrutiny Board, is complex and it remains to be seen whether it delivers results (PACT European Affairs, 2015).

Correct and timely transposition of EU directives by member states is crucial for the functioning of the Single Market. Improvement in the pace and the quality of transposition is reflected in the declining number of infringement cases as well as in the low number of directives that at least one member state failed to transpose, the so-called incompleteness rate, both currently at long-term lows (Figure 18). The quality and timeliness of the process has been enhanced by information sharing tools, such as the EU Pilot and SOLVIT, designed to solve compliance problems without resorting to infringement proceedings. Based on voluntary compliance, both schemes have achieved resolution rates above $70 \%$ and declining average times of handling cases (Pelkmans and Correia de Brito, 2012). These pre-infringement initiatives should be given sufficient resources, including staff, to ensure their successful continuation.

Figure 18. Internal market scoreboard indicators ${ }^{1}$

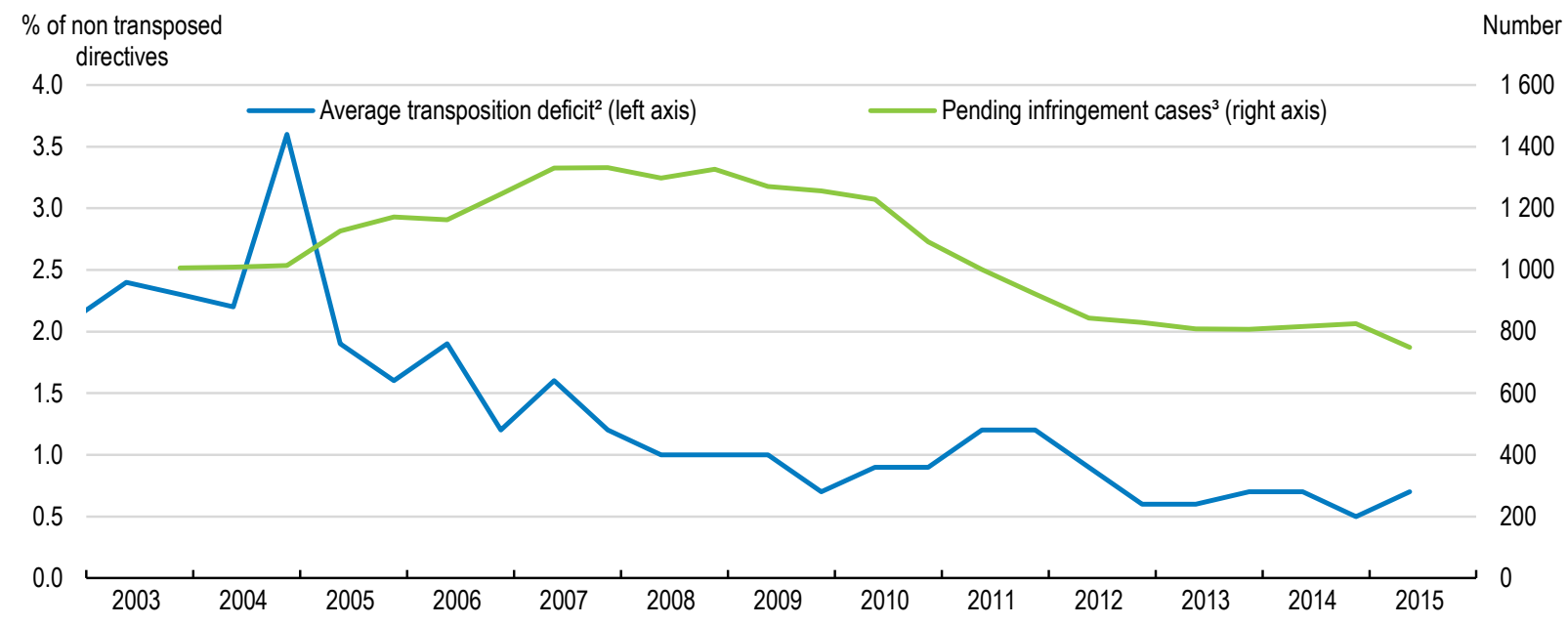

1. European Union changing composition.

2. Transposition notifications made by 10 May 2015, for directives with a transposition deadline of 30 April 2015 .

3. Infringement proceedings open on 1 May 2015.

Source: European Commission (2015), Single Market Scoreboard, October, http://ec.europa.eu/internal_market/scoreboard. 


\section{Regulatory co-operation in regional trade agreements}

Regional trade agreements (RTAs) could be important regulatory co-operation instruments, as they often include provisions on competition, domestic regulation, technical standards or transparency of rules (OECD, 2013b). Achieving regulatory convergence may require prolonged negotiations and a similar level of ambition. Less comprehensive and binding schemes of international regulatory co-operation may lead to lower compliance unless supported by other institutions, including multilateral forums and international organisations (OECD, 2015d). Looking at existing preferential trade agreements, it appears that regulatory compatibility can be achieved more effectively through strong institutional mechanisms, such as joint committees that meet on a regular basis than with bilateral committees comprised of government officials that only meet once a year (Steger, 2012).

The Transatlantic Trade and Investment Partnership (TTIP), if agreed, would remove barriers to trade and investment and develop a new model of integration based on a permanent bilateral regulatory cooperation mechanism including horizontal provisions as well as a number of sector-specific commitments (Alemanno, 2015). Importantly, the creation of a permanent institutional mechanism will allow the identification of new areas of co-operation without re-opening the initial international agreement.

Governments are facing an increasing number of arbitration claims by foreign investors (Gaukrodger and Gordon, 2012) and the evidence on positive effects of international investor protection on investment flows remains inconclusive (Poulsen et al., 2015). Since the entry into force of the Lisbon Treaty and the transfer of competence for foreign direct investment as part of the common commercial policy, the European Union has started a reform of investor protection and dispute settlement system with the main aim of finding the right balance between investor protection and safeguarding the EU's and its member states' right to regulate. The investor-to-state dispute settlement (ISDS) mechanism, based on arbitration, has been criticised for possible discrimination between domestic and foreign investors, the ways of selecting and regulating the arbitrators and the lack of decision-making consistency (Gaukrodger and Gordon, 2012). The Commission's proposal to replace the ISDS by a permanent system of investment courts reflects the negative feedback from the public consultation and incorporates welcome elements, such as early dismissal of unfounded claims and independence of judges (Baetens, 2015).

\section{Key sectoral policies to lift potential growth}

\section{Services liberalisation}

In the process of transposition of the Services Directive, member states could maintain a number of regulatory requirements if they assessed them as non-discriminatory, necessary and proportionate. As a result, EU trade in services remains subject to administrative and other barriers that vary considerably across individual countries (Figure 19). There are indications that unjustified and disproportionate requirements are still widespread and that regulation of professions varies substantially among the member states (OECD, 2014a; European Commission, 2015c). Moreover, between 2012 and 2014, the most restrictions have been removed in countries under financial assistance, while other member states either did not act on their services-related country-specific recommendations or even introduced new barriers (European Commission, 2015d). 
Figure 19. Services trade restrictiveness index

Index scale from 0 (completely open) to 1 (completely closed), $2015^{1}$
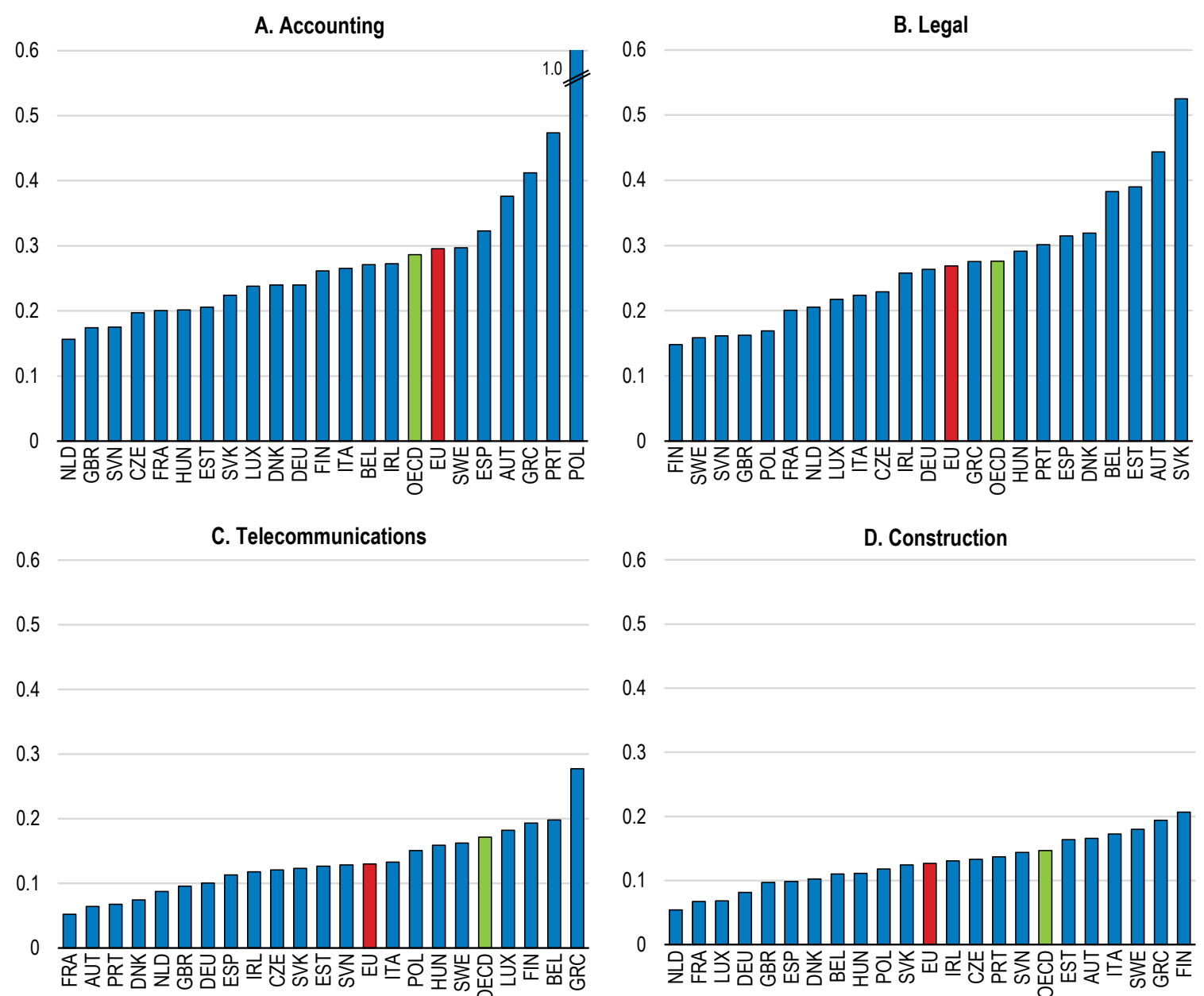

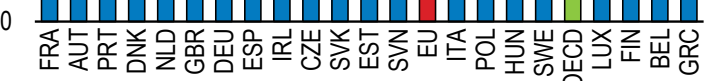

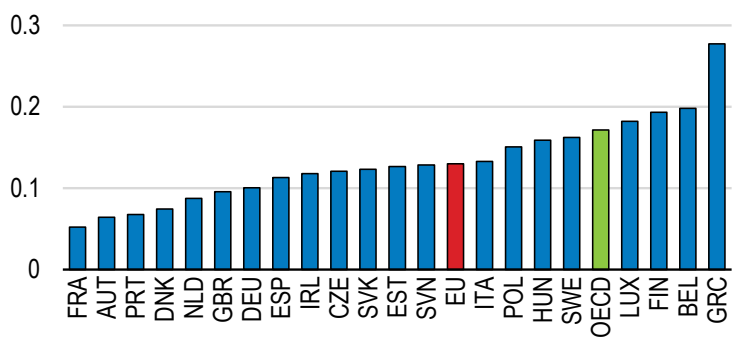

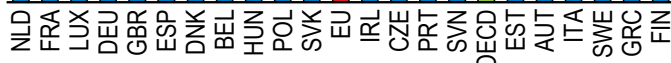

1. Measures included in the index cover restrictions on foreign entry and movement of people, barriers to competition, regulatory transparency and other discriminatory measures. Aggregates are unweighted averages; the European Union covers member countries that are also members of the OECD (21 countries).

Source: OECD (2016), Services Trade Restrictiveness Index Regulatory Database.

Companies providing cross-border services often lack reliable information on applicable administrative requirements, such as the rules governing the posting of workers. The rules, especially regarding social security and income taxation, are often perceived as unclear (European Commission, 2015b). Provision by the Commission of reliable information, the introduction of harmonised forms and the introduction of an electronic services passport using single electronic notification procedure and a common electronic repository of documents to eliminate the need for multiple requests for information and documentation are welcome and should lower compliance costs (European Commission, 2015c).

Besides reducing administrative burdens, electronic services passports could be used to achieve other goals, such as facilitating temporary cross-border service provision and secondary establishment. Common rules concerning selected sector-specific requirements, such as the legal form of companies, admissible management requirements and minimum health and safety standards, could be considered with a view of leading toward mutual recognition. Further legislative action foreseen in the Single Market strategy could help reduce remaining regulatory barriers in key business and construction services. 


\section{Digital Single Market}

Digitalisation facilitates diffusion and replication of innovative ideas, and together with information and communication technology (ICT) is likely to remain a key driver of productivity growth, especially in advanced, frontier economies (Brynjolfsson and McAfee, 2011; OECD, 2015e). Digital technologies raise GDP growth through ICT-induced labour productivity improvements and the measures of accumulated ICT capital stock show a persistent gap between Europe and the United States (Figure 20). Although the digital economy is growing quickly, the scope for further uptake remains considerable, as consumers account only for a small fraction of e-commerce, with some $90 \%$ of the value of e-commerce being transactions between businesses (OECD, 2015f).

Figure 20. Information, communication and technology (ICT) capital stock ${ }^{1}$

As a percentage of GDP
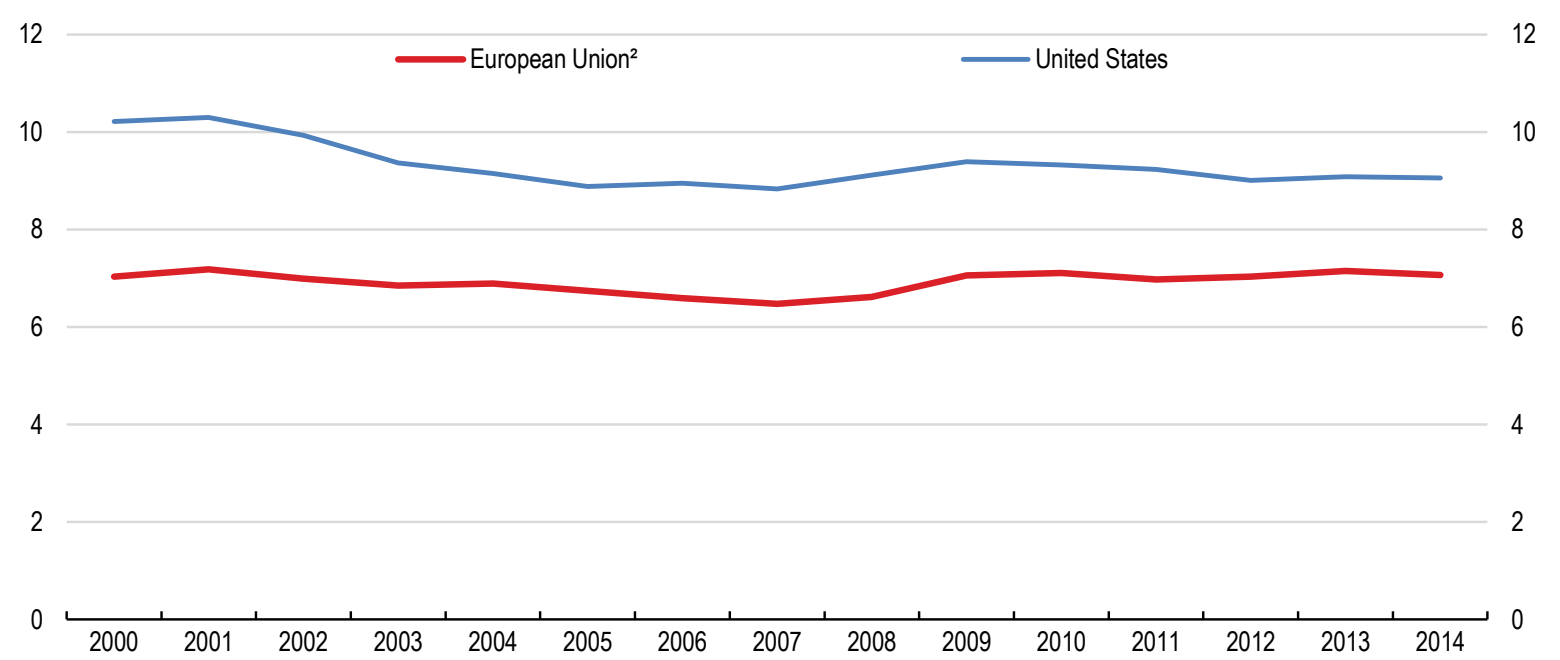

1. Net fixed assets in current prices for total activities. ICT covers ICT equipment (computer hardware and telecommunications equipment) plus computer software and databases.

2. Unweighted average of the 15 countries for which data is available; 2014 is an estimate.

Source: OECD (2016), OECD National Accounts Statistics (database).

Complex consumer protection rules can discourage consumers and SMEs from engaging in crossborder e-commerce. The Commission proposes to tackle the issue by further harmonising rules for online purchases (European Commission, 2015e). A comprehensive framework for consumer rights for online sale of tangible goods is already provided by EU laws, such as the Consumer Rights directive. In contrast, consumer protection for online purchases of digital content seems inadequate in many member states (BEUC, 2015). The effort should be directed at consumer protection of digital content purchases, while avoiding discrepancies in consumer protection between online and offline purchases of tangible goods.

The gradual elimination of roaming surcharges in mobile telecommunications is an important step towards an EU telecoms market, as it should reduce price differences for consumers between networks at home and abroad. But this should be followed by limited additional co-ordination in aspects such as spectrum assignment and by cross-country regulatory harmonisation. Co-ordinated spectrum auctioning at the EU level, while respecting the fact that markets will remain regulated on a national basis for the foreseeable future, could lead to a reduction in participation costs and make auctions more predictable for bidders (Mariniello and Salemi, 2015). 


\section{The Energy Union}

The Energy Union is a welcome opportunity to achieve the "triple" objective of energy security, decarbonisation and competitiveness (Helm, 2015). The initial focus of EU energy policies on liberalisation and unbundling created necessary, but not sufficient, conditions for a well-functioning EU market. However, the full benefits of this effort have not yet fully materialised due to missing elements, such as interconnection between member states, common regulation for grid and pipeline access and common accounting basis for charging fees. The inefficiency of the EU energy market, and the corresponding potential for gains from trade, is illustrated by the substantial dispersion of energy prices across the European Union (Figure 21). On the other hand, the intended benefits of the EU energy market has been reduced by developments in climate policy and renewable energy support, such as provision of renewables at zero marginal cost, leading to a misalignment between the functioning of wholesale electricity markets and decarbonisation policies (OECD/IEA/NEA/ITF, 2015).

\section{Figure 21. Electricity prices for industry}

EUR per megawatt hour, before taxes, $2015^{1}$

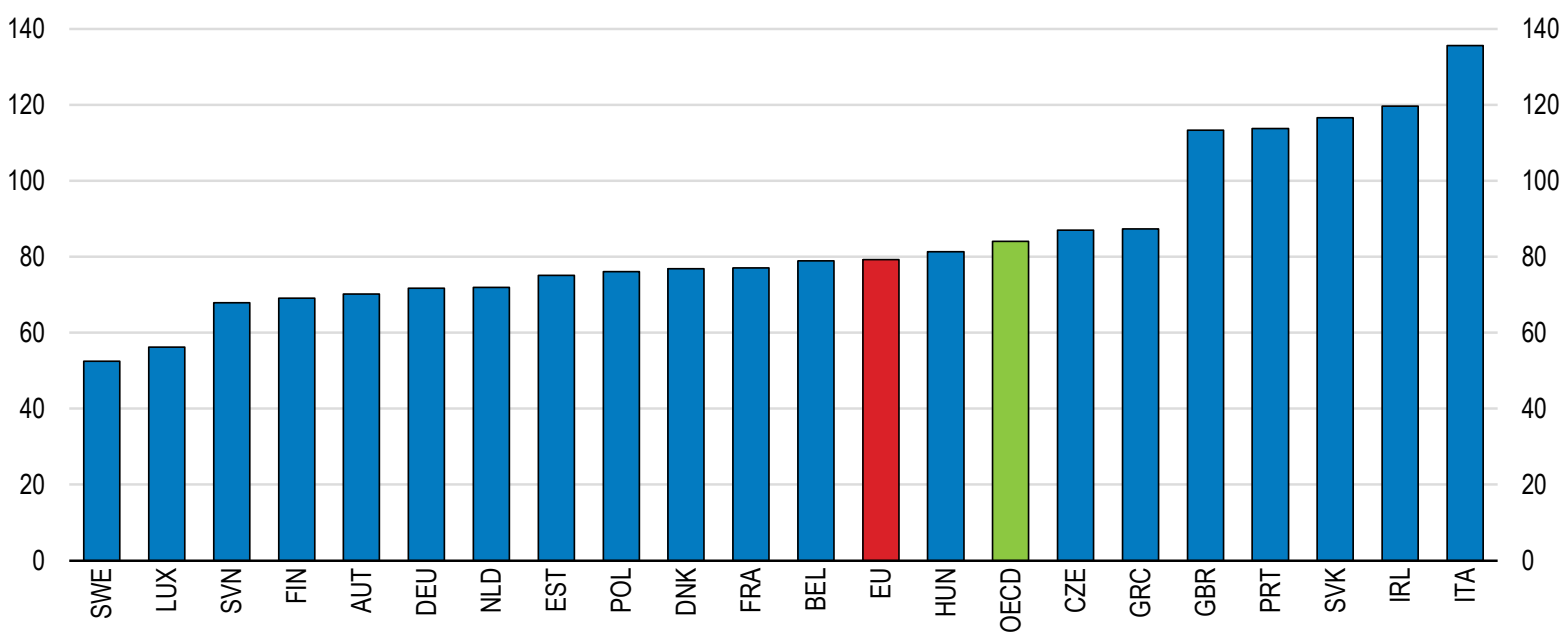

1. 2014 for Germany, Greece, Netherlands and United Kingdom. Aggregates are unweighted averages of latest data available. The European Union covers member countries that are also members of the OECD (21 countries) excluding Spain (no data available) and the OECD covers 29 countries.

Source: IEA (2016), IEA Energy Prices and Taxes Statistics and OECD (2016), OECD Economic Outlook: Statistics and Projections (databases).

Better interconnections help create more efficient electricity markets, encourage more competition and could alleviate the variability of flows associated with renewables generation (IEA, 2014). While most of the EU wholesale electricity markets are coupled to one or more neighbours, showing signs of price convergence, marked price differentials remain with regard to gas, partly due to long-term contracts and missing interconnections (European Commission, 2015f). The "triple" objective is politically difficult, but feasible, if one employs a top-down strategy, a credible estimate of the gains from fully integrated energy markets to build consensus and a centralised outline of European gas and electricity grids (Helm, 2015).

The Energy Union should ensure flexibility in the energy sector by increased interconnectivity. The European clean energy strategy should be put in place to ensure that the Investment Plan for Europe and other EU funds are channelled to the investment needs of the Energy Union to ensure that publicly-backed investment is used to deliver on European energy security and climate goals (Gaventa et al., 2015). 
Disconnection between the EU energy policy and its climate policy should be eliminated or reduced following the recent COP21 agreement. In this vein, the Energy Union strategy based on five related and mutually reinforcing dimensions, now includes the 2030 Climate and Energy Policy Framework, in which the European Union contributed a collective pledge to reduce domestic greenhouse gas (GHG) emissions by at least $40 \%$ below 1990 levels by 2030 (the target entails reductions in the Emissions Trading System [ETS] and non-ETS sectors amounting to $43 \%$ and 30\% respectively compared to 2005 levels). In this context, it is worth noting that although the reduction of emissions by $19 \%$ achieved since 1990 is partly the result of the structural changes in member states that joined after 2004 and of the consequences of the global financial and economic crisis, concerted policy effort, such as the support of renewables, has contributed to this outcome (IEA, 2014). After 2008, an increasing decoupling of economic growth and energy consumption could also be observed, notably driven by a comprehensive set of energy efficiency policies. The other elements of the 2030 framework include a binding EU level target for a minimum 27\% share of renewable sources in energy consumption, an indicative EU level target of $27 \%$ improvement in energy efficiency and an electricity interconnection target of $15 \%$ by 2030 . The effort going forward will require not only a shift to low-carbon and renewable sources of energy, but also improved resource efficiency, including more recycling and a reduction of raw material use (Behrens, 2016).

The EU climate and energy policies need to ensure balance between sustainability, competitiveness and security of supply. Strengthening market-based measures (including a reform of the ETS), a competitive electricity market and a stable regulatory framework for low-carbon technologies will all be needed to deliver the 2030 targets. As part of the energy market liberalisation, energy subsidies that are still often used to lower energy prices should be phased out (IEA, 2014). Instead, a three-pillar approach, including carbon pricing (a more robust ETS and taxes on non-ETS sectors, where appropriate), targeted energy efficiency regulations ensuring rational energy use and support for low-carbon technologies, should be put in place (OECD/IEA/ITF/NEA, 2015). Carbon taxes or trading systems, such as those that are in place in the European Union, can raise revenues, creating room for reduction of other more distorting taxes, and establish price signals (IMF, 2016).

\section{Transportation}

The Single Market would profit from improved and more competitive transport services in road, rail, air and maritime transport. Road freight transport is the main inland transport mode in the European Union. As more than $90 \%$ of all national road transport activity in each country is still carried out by domestically registered vehicles, the market remains uncompetitive and highly segmented along the national borders. Competition could be improved by opening up the domestic markets to operators from other EU countries. Reducing restrictions on international transport and cross-border provision of services (cabotage), such as restrictive provisions applying to type of goods mainly transported by non-resident hauliers, and more stringent enforcement of existing rules could help in doing so (European Commission, 2014). The international bus and coach transport inside the EU has been mostly liberalised and operators with a Community licence issued in their home country have free access to the whole international road transport market.

Completion of the single European railway area would further increase competition in railway transport and reduce costs of public services contracts. The fourth railway package, in its recently agreed technical pillar, will strengthen the role of the European Railway Agency as authority in certification and approval of vehicles. This is a key precondition for an EU-wide railway market, since technical characteristics of national networks, such as signalling and circulation rules, electricity supply and even the tracks width can diverge (Savy et al., 2013). Agreement is also building up on non-discriminatory access to the railway networks and competitive tendering of public service contracts that will open up the domestic markets to cross-border competition, increasing quality of service and cost efficiency. Although targeted measures may be needed to ensure impartiality of infrastructure managers in vertically integrated 
structures and address risks of cross-subsidisation, existing evidence from European countries suggests that competitive tendering could lead to cost savings of at least $20 \%$ in both service provision (European Commission, 2013) and infrastructure maintenance (Odolinski and Smith, 2014).

The European airspace is still fragmented, partly because the air traffic management remains fragmented and suffering from a lack of co-ordination, leading to longer flight routes with greater environmental footprint, due to pockets of restricted airspace, and unnecessary delays and costs in service provision (OECD, 2014a). The progress with the Single European Sky framework, including the modernisation of Eurocontrol agreed in 2013, is welcome, especially in the area of the performance scheme, network operation and technological modernisation, and may gradually lead to a less fragmented European airspace (European Commission, 2015g). The Commission's aviation strategy that calls for optimising the use of EU airports and monitoring both intra-EU and extra-EU connectivity to identify shortcomings is also welcome.

\section{Box 1. Recommendations on priorities for completing the Single Market}

\section{Structural reforms to support the recovery and improve adjustment to shocks}

\section{Developing market-based financing alternatives for firms}

Key recommendations

- $\quad$ Ease the regulatory treatment of simple, transparent and standardised securitisation to unlock lending to small and medium-sized enterprises.

- Collect and share internationally comparable credit information on smaller firms.

- Lower capital requirements for long-term and infrastructure investment.

- $\quad$ Lower the regulatory barriers in corporate bond markets by addressing issues in securities ownership and harmonising insolvency proceedings.

\section{Additional recommendation}

- Further harmonise the local rules for financial trading and improve the settlement infrastructure, in order to reduce operational costs for market participants.

\section{Enhancing labour market mobility and integration}

Key recommendations

- Reduce the administrative burden associated with recognition of professional qualifications by using electronic procedures such as the European Professional Card.

- Legislate effective portability of supplementary pension rights.

- Simplify the eligibility requirements and procedures of the Blue Card scheme to make it more attractive to non-EU high-skilled labour migrants than existing schemes.

- Strengthen joint protection of external borders.

- Speed up administrative decisions on asylum applications and ease labour market access for recognised refugees.

\section{Additional recommendations}

- Provide publicly funded language training tailored to mobile workers, so as to increase the intra-EU labour mobility.

- Develop common rules for an EU-wide treatment of double taxation issues related to pensions, incomes of cross-border commuters and posted workers and improve the portability of social benefits. 
ECO/WKP(2016)39

\section{Structural reforms to boost potential growth}

\section{Better regulation}

\section{Key recommendation}

- Improve the quality of impact assessment of legislative proposals, notably amendments, and the quality of ex post evaluation of policies.

\section{Additional recommendation}

- Use electronic services passport, harmonised forms and common rules concerning selected sector-specific requirements to reduce administrative burdens for service providers and regulatory barriers in the services sector.

\section{Network services sectors}

\section{Key recommendations}

- Harmonise the rules for online purchases and reduce unjustified geographical discrimination of consumers.

- Harmonise, taking into account the specificities of each member state, national regulations and technical specifications in network sectors, with the target of transferring decision powers in technical matters to a single EU regulator.

- $\quad$ Prioritise the Trans-European transport and energy network projects to support the completion of the Single Market.

\section{Additional recommendations}

- $\quad$ Support a single market in wireless networks by introducing co-ordinated multi-national EU-wide spectrum auctions and by increasing the convergence of spectrum selection processes and assignment conditions.

- $\quad$ Strengthen the Single Market by ensuring more competitive transport services by opening up domestic road transportation to operators from other countries and completing the single European railway area. 


\section{Bibliography}

d'Addio, A. and M. Cavalleri (2015), "Labour mobility and the portability of social right in the EU", CESifo Economic Studies, Vol. 61, 2/2015, pp. 346-376, Oxford University Press.

AFME (2016), "Potential economic gains from reforming insolvency law in Europe", Association for Financial Markets in Europe, Brussels.

Aghion, P. et al. (2009), "The effects of entry on incumbent innovation and productivity", Review of Economics and Statistics, Vol. 91, No. 1, pp. 20-32, MIT Press.

Ahrend, R., J. Arnold and C. Moser (2011), "The sharing of macroeconomic risk: Who loses (and gains) from macroeconomic shocks", OECD Economic Department Working Papers, No. 877, OECD Publishing, Paris, http://dx.doi.org/10.1787/5kg8hw5467wd-en.

Alemanno, A. (2015), "The regulatory cooperation chapter of the Transatlantic Trade and Investment Partnership: Institutional structures and democratic consequences", Journal of International Economic Law, Vol. 18, No. 3, Oxford Journals.

Baetens, F. (2015), "Transatlantic investment treaty protection - A response to Pouslen, Bonnitcha and Yackee", Chapter 6 in D. Hamilton and J. Pelkmans (eds.), Rule-Makers or Rule-Takers? Exploring the Transatlantic Trade and Investment Partnership, Johns Hopkins University School of Advanced International Studies, Washington, DC and Centre for European Policy Studies, Brussels.

Behrens, A. (2016), "Time to connect the dots: What is the link between climate change policy and the circular economy?", CEPS Policy Brief, No. 337, Centre for European Policy Studies, Brussels.

Bénassy-Quéré, A. (2010), Economic Policy: Theory and Practice, Oxford University Press, Oxford.

Bénassy-Quéré, A., C. Schwellnus, and D. Ünal-Kesenci (2006), "International trade: Services included”, Lettre du CEPII, No. 255, Centre d'études prospectives et d'informations internationales, Paris.

BEUC (2015), “A consumer-driven Digital Single Market”, The European Consumer Organisation, Brussels.

Blanchard, O. and A. Giavazzi (2003), "Macroeconomic effects of regulation and deregulation in goods and labour markets", Quarterly Journal of Economics, Vol. 122, No. 58, pp. 349-402, Oxford Journals.

Braconier, H. and M. Pisu (2013), "Road connectivity and the border effect: Evidence from Europe", OECD Economics Department Working Papers, No. 1073, OECD Publishing, Paris, http://dx.doi.org/10.1787/5k43nxmh51mw-en.

Braconier, H. and J. Ruiz-Valenzuela (2014), "Gross earning inequalities in OECD countries and major non-member economies: Determinants and future scenarios", OECD Economics Department Working Papers, No. 1139, OECD Publishing, Paris, http://dx.doi.org/10.1787/5jz123k7s8bv-en.

Bresnahan, T.F., E. Brynjolfsson and L.M. Hitt (2002), "Information technology, workplace organization, and the demand for skilled labor: Firm-level evidence", Quarterly Journal of Economics, Vol. 117, No. 1, pp. 339-376, Oxford University Press. 
Brynjolfsson, E. and A. McAfee (2011), Race Against the Machine: How the Digital Revolution is Accelerating Innovation, Driving Productivity, and Irreversibly Transforming Employment and the Economy, Digital Frontier Press.

Caldera Sánchez, A., A. de Serres and N. Yashiro (2016) "Reforming in a difficult macro context: A review of the issues and recent literature", OECD Economics Department Working Papers, No. 1297, OECD Publishing, Paris.

Causa, O., A. de Serres and N. Ruiz (2015), "Can pro-growth policies lift all boats? An analysis based on household disposable income", OECD Journal: Economic Studies, Vol. 2015/1, http://dx.doi.org/10.1787/eco_studies-2015-5jrqhbb1t5jb.

CEPS (2014), "Making the most of EU labour mobility", Report of a CEPS Task Force, Rapporteurs: M. Barslund and M. Busse, Centre for European Policy Studies, Brussels.

Chaloff, J. (2016), "The impact of EU Directives on the labour migration framework in EU countries", OECD Social, Employment and Migration Working Papers, forthcoming.

Chaloff, J., et al. (2012), "Free labour mobility and economic shocks: the experience of the crisis", in OECD, Free Movement of Workers and Labour Market Adjustment: Recent Experiences from OECD Countries and the European Union, OECD Publishing, Paris, http://dx.doi.org/10.1787/9789264177185-5-en.

Cœuré, B. (2015), "Capital Markets Union in Europe: an ambitious but essential objective”, A speech at the Institute for Law and Finance in Frankfurt, 18 March.

Dao, M., D. Furceri and P. Loungani (2014), "Regional labour market adjustments in the US and Europe", IMF Working Paper, WP/14/26, International Monetary Fund, Washington DC.

ECB (2015), Financial Integration in Europe, European Central Bank, Frankfurt am Main.

Engel, C. and J.H. Rogers (1996), "How wide is the border?", American Economic Review, Vol. 6, No. 5, pp. 1112-1125, American Economic Association.

Erceg, C.J. and J. Lindé (2010), “Asymmetric shocks in a currency union with monetary and fiscal handcuffs", in R. Clarida and F. Giavazzi (eds.), NBER International Seminar on Macroeconomics 2010, pp. 95-135, University of Chicago Press.

EUA (2014), "EUA Briefing note on Directive 2013/55/EU, containing the amendments to Directive 2005/36/EC on the Recognition of Professional Qualifications", European University Association, Brussels.

Eurofound (2015), “The thorny issue of labour mobility: Hotly debated but still a slow burner", Foundation Focus, December.

European Commission (2015a), "Erasmus - Facts, figures and trends. The European Union support for student and staff exchanges and university cooperation in 2013-14", European Commission, Brussels.

European Commission (2015b), "Better regulation for better results: An EU agenda", Communication $\operatorname{COM}(2015) 215$ final, European Commission, Brussels. 
European Commission (2015c), "Upgrading the Single Market: more opportunities for people and business", $\operatorname{COM}(2015) 550$ final, Brussels.

European Commission (2015d), "Assessment of the economic impact of the Services Directive: Update of the 2012 study", European Commission, Brussels.

European Commission (2015e), “A Digital Single Market Strategy for Europe”, Commission Communication $\operatorname{COM}(2015) 192$ final, 6 May.

European Commission (2015f), "State of the Energy Union 2015", Communication COM(2015) 572 final, European Commission, Brussels.

European Commission (2015g), "Report from the Commission to the Parliament and the Council on the implementation and progress of the Single European Sky during 2012-2014 period", COM(2015) 663 final, European Commission, Brussels.

European Commission (2014), "Report from the Commission to the Parliament and the Council on the state of the Union road transport market", $\operatorname{COM}(2014) 222$ final, European Commission, Brussels.

European Commission (2013), "Impact Assessment accompanying the proposals for Regulation 1370/2007 and Directive 2012/34/EU concerning the opening of the market for domestic passenger transport services by rail”, SWD(2013) 10 final Part 1, European Commission, Brussels.

European Commission (2011), "Report on the application of Directive 2003/109/EC concerning the status of third-country nationals who are long-term residents", Report COM (2011) 585 final, European Commission, Brussels.

European Commission (2010), “Geographical and labour market mobility”, Eurobarometer Special Survey No. 337, European Commission, Brussels.

Fournier, J. (2015), "The heterogeneity of product market regulations", OECD Economics Department Working Papers, No. 1182, OECD Publishing, Paris, http://dx.doi.org/10.1787/5js7xhxwrnwd-en.

Fournier, J., A. Domps, Y. Gorin, X. Guillet and D. Morchoisne (2015), "Implicit regulatory barriers in the EU single market: New empirical evidence from gravity models", OECD Economics Department Working Papers, No. 1181, OECD Publishing, Paris, http://dx.doi.org/10.1787/5js7xj0xckf6-en.

Furceri, D. and A. Zdzienicka (2013), "The euro area crisis: Need for a supranational fiscal risk sharing mechanism?”, IMF Working Paper, WP/13/198, International Monetary Fund, Washington DC.

Gaukrodger, D. and K. Gordon (2012), "Investor-state dispute settlement: A scoping paper for the investment policy community", OECD Working Papers on International Investment, No. 2012/03, OECD Publishing, Paris, http://dx.doi.org/10.1787/5k46b1r85j6f-en.

Gaventa, J., N. Mabey, S. Dixson-Declève, H. Spence-Jackson and D. Acke (2015), "EU Energy Union Assessment 2015: Towards a resilient Energy Union with a forward-looking climate policy", E3G Briefing Paper.

de Grauwe, P. (2014), Economics of Monetary Union, 10th Edition, Oxford University Press.

Helm, D. (2015), “The EU Energy Union: More than the sum of its part?”, Centre for European Reform, London. 
IEA (2014), Energy Policies of IEA Countries: European Union 2014 Review, International Energy Agency, Paris, http://dx.doi.org/10.1787/9789264190832-en.

IMF (2016), "After Paris: Fiscal, macroeconomic, and financial implications of climate change", IMF Staff Discussion Note, No. 16/01, International Monetary Fund, Washington DC.

IMF (2015), “A strategy for resolving Europe's problem loans”, IMF Staff Discussion Note, SDN/15/19, International Monetary Fund, Washington DC.

IMF (2013), "Toward a fiscal union for the euro area”, IMF Staff Discussion Note, SDN/13/09, International Monetary Fund, Washington DC.

Jauer, J., T. Liebig, J.P. Martin and P. Puhani (2014), "Migration as an adjustment mechanism in the crisis? A comparison of Europe and the United States", OECD Social, Employment and Migration Working Papers, No. 155, OECD Publishing, Paris, http://dx.doi.org/10.1787/5jzb8p51gvhl-en.

Kaya, O. (2015), "Capital markets union: An ambitious goal, but few quick wins", EU Monitor Global Financial Markets, Deutsche Bank Research, Frankfurt am Main.

Mariniello, M. and F. Salemi (2015), “Addressing fragmentation in EU mobile telecoms markets", Bruegel Policy Contribution, No. 2015/13, Bruegel, Brussels.

Nordås, H.K. and H. Kox (2009), "Quantifying regulatory barriers to services trade”, OECD Trade Policy Papers, No. 85, OECD Publishing, Paris, http://dx.doi.org/10.1787/5kgkcjqsm6kd-en.

Odolinski, K. and A.S.J. Smith (2014), "Assessing the cost impact of competitive tendering in rail infrastructure maintenance: evidence from the Swedish reforms (1999-2011), CTS Working Paper, No. 2014:17, Centre for Transport Studies, Stockholm.

OECD (2016), OECD Economic Surveys: European Union 2016, OECD Publishing, Paris, http://dx.doi.org/10.1787/eco_surveys-eur-2016-en

OECD (2015a), OECD Business and Finance Outlook 2015, OECD Publishing, Paris, http://dx.doi.org/10.1787/9789264234291-en.

OECD (2015b), Economic Policy Reforms 2015: Going for Growth, OECD Publishing, Paris, http://dx.doi.org/10.1787/growth-2015-en.

OECD (2015c), International Migration Outlook 2015, OECD Publishing, Paris, http://dx.doi.org/10.1787/migr_outlook-2015-en.

OECD (2015d), OECD Regulatory Policy Outlook 2015, OECD Publishing, Paris, http://dx.doi.org/10.1787/9789264238770-19-en.

OECD (2015e), The Future of Productivity, OECD Publishing, Paris, http://dx.doi.org/10.1787/9789264248533-en.

OECD (2015f), OECD Digital Economy Outlook 2015, OECD Publishing, Paris, http://dx.doi.org/10.1787/9789264232440-en.

OECD (2014a), OECD Economic Surveys: European Union 2014, OECD Publishing, Paris, http://dx.doi.org/10.1787/eco_surveys-eur-2014-en. 
OECD (2014b), OECD Economic Surveys: Hungary 2014, OECD Publishing, Paris, http://dx.doi.org/10.1787/eco_surveys-hun-2014-en.

OECD (2013a), Recruiting Immigrant Workers: Germany 2013, OECD Publishing, Paris, http://dx.doi.org/10.1787/9789264189034-en.

OECD (2013b), International Regulatory Co-operation: Addressing Global Challenges, OECD Publishing, Paris, http://dx.doi.org/10.1787/9789264200463-en.

OECD/IEA/NEA/ITF (2015), Aligning Policies for a Low-carbon Economy, OECD Publishing, Paris, http://dx.doi.org/10.1787/9789264233294-en.

PACT European Affairs (2015), "The Better Regulation package and Inter-institutional Agreement: What does it mean for EU public affairs?", PACT European Affairs, Brussels, www.pacteurope.eu/pact/wp-content/uploads/2015/06/PACT_Better_Regulation_booklet_2015.pdf.

Pelkmans, J. and A. Correia de Brito (2012), Enforcement in the EU Single Market, Centre for European Policy Studies, Brussels.

Pina, A. (2016), "Making public finances more growth and equity-friendly in the euro area", $O E C D$ Economics Department Working Papers, No. 1316, OECD Publishing, Paris.

Poulsen, L., J. Bonnitcha and J. Yackee (2015), "Transatlantic investment treaty protection", Chapter 5 in D. Hamilton and J. Pelkmans (eds.), Rule-Makers or Rule-Takers? Exploring the Transatlantic Trade and Investment Partnership, Johns Hopkins University School of Advanced International Studies, Washington DC and Centre for European Policy Studies, Brussels.

Reiff, Á. and F. Rumler (2014), "Within- and cross-country price dispersion in the euro area", $E C B$ Working Paper, No. 1742, European Central Bank, Frankfurt am Main.

Renda, A. (2015), "Too good to be true? A quick assessment of the European Commission's new Better Regulation Package”, CEPS Special Report, No. 108, Centre for European Policy Studies, Brussels.

Savy, M. et al. (2013), "Transport management as a key logistics issue", Chapter 9 in P. Wieser et al. (eds.), Essentials of Logistics and Management: The Global Supply Chain, EPFL Press, 3rd edition.

Steger, D. (2012), "Institutions for regulatory cooperation in 'New Generation' economic and trade agreements", Legal Issues of Economic Integration, Vol. 39, No. 1, pp. 109-126, Kluwer Law Online.

Valiante, D. (2015), "Light and shadows in Europe's new Action Plan for Capital Markets Union", CEPS/ECMI Commentary, No. 40/5, Centre for European Policy Research, Brussels.

Véron, N. and G. Wolff (2015), "Capital markets union: A vision for the long term", Bruegel Policy Contribution, No. 2015/05, Bruegel, Brussels.

Zangari, E. (2014), "Addressing the debt bias: A comparison between the Belgian and the Italian ACE Systems", Taxation Papers, No. 44, European Commission, Brussels. 
ECO/WKP(2016)39

Annex A.1.

\section{Quantification of the impact of recommended structural reforms}

The quantification of structural reforms is based on the OECD's Going for Growth framework of policy indicators and empirical estimates of the relationship between policy and economic outcomes, which is rooted in an extensive research programme over many years to understand these relationships. A similar methodology has been used in previous work by the OECD, including the IMF-OECD exercise for the G-20 Brisbane Summit in 2014, which evaluated the contribution of growth strategies by G-20 countries at $2.1 \%$ growth of the world's gross domestic product (GDP).

The quantitative assessment documented in this report focuses on the macroeconomic effects of competition-enhancing reforms advocated through a set of key policy recommendations. It proceeds in two steps: first, the magnitude of the reduction in barriers to competition implied by each key recommendation is evaluated on the basis of OECD product market regulation (PMR) indicators. Second, the estimated changes in the PMR indicator from selected key recommendations (those suitable for quantification) are in turn transposed into associated productivity and GDP gains, based on the empirical findings from previous OECD studies.

The reform scenario corresponds to a subset of the key recommendations to reduce barriers to capital and labour mobility, as well as to entry and competition through better regulation, in particular in the areas of professional services and network sectors. Each quantifiable recommendation is linked to the relevant area of reform in the overall PMR indicator (Table A.1). Technically, the quantified effect is that of a reduction in the level of product market regulation on multifactor productivity, i.e. the first (and quantitatively the most important) of the eight channels identified in the IMF-OECD exercise for G-20.

Table A.1. List of quantified key recommendations

Area of reform

Barriers to entrepreneurship Barriers in services

2 Barriers to entrepreneurship -

Communication and simplification of rules and procedures

3 Barriers to entrepreneurship Barriers in network sectors
Recommendation

Reduce the administrative burden associated with recognition of professional qualifications by using electronic certificates.

Improve the quality of impact assessment for legislative proposals and the quality of ex post evaluation policies.

Harmonise the rules for online purchases and reduce geographical discrimination of consumers.

Prioritise the Trans-European transport and energy network projects to support the completion of the Single Market.

Harmonise national regulations and technical specifications in network sectors, with the target of transferring decision powers in technical matters to a single EU regulator.

Some of the key recommendations do not lend themselves to quantification and are not included in this exercise. In general, the mapping of reform recommendations into changes in corresponding PMR components is not perfect and necessarily involves judgement. For two of the recommendations, PMR questions on communication and simplification of rules and procedures have been used as a basis for quantification. The recommendation to improve regulatory quality, which includes a reinforcement of the EU Regulatory Fitness (REFIT) programme, has been quantified as a reduction in the administrative burden. Changes in the PMR indicators by area of reform and by country are summarised in Table A.2. 
Table A.2. Reduction in the product market regulation (PMR) indicator ${ }^{1}$

Per cent

\begin{tabular}{|c|c|c|c|c|c|c|}
\hline Area of reform & Total & France & Germany & Italy & Spain & $\begin{array}{l}\text { United } \\
\text { Kingdom }\end{array}$ \\
\hline $\begin{array}{l}\text { Barriers to entrepreneurship - Barriers in } \\
\text { services }\end{array}$ & 2.57 & 2.52 & 2.86 & 3.91 & 2.57 & 1.14 \\
\hline $\begin{array}{l}\text { Barriers to entrepreneurship - Communication } \\
\text { and simplification of rules and procedures }\end{array}$ & 1.42 & 1.51 & 1.38 & 1.56 & 1.61 & 1.15 \\
\hline Barriers in network sectors & 2.12 & 2.41 & 2.47 & 2.48 & 1.67 & 1.31 \\
\hline
\end{tabular}

1. The changes are calculated with respect to the latest PMR data available (2013).

Since a PMR-based quantification exercise cannot yield estimates of impacts from reforms in several important areas, and the macroeconomic impact of structural reforms is in any case uncertain and sensitive to model assumptions, the approach pursued in this annex can be usefully complemented by a literature review on the quantification of structural reforms in the EU context to give a broader range of potential estimates (Box A.1).

\section{Box A.1. Literature on the quantification of EU structural reforms}

A number of studies look at reforms in several policy areas. Varga and in't Veld (2014) employ the Commission's dynamic stochastic general equilibrium model QUEST and find significant gains in output and employment if countries close the gap with respect to the best EU performers in a broad set of areas (including tax structure, research and development expenditure, labour market participation, active labour market policies, regulation in product markets). The simulations suggest an increase in EU gross domestic product (GDP) of $3 \%$ after five years and $6 \%$ after ten years.

European Commission (2016) studies a subset of reforms from National Reform Programmes of Italy, France, Spain and Portugal that could be realistically quantified, thus providing a conservative estimate of the impact of those countries' reform efforts. Simulations, again using the QUEST model, suggest GDP increases between $1 \frac{11 / 4}{4}$ and $2 \%$ by 2020 .

Other studies focus on reforms in individual policy areas. More specifically, the main findings for some of the key areas of reforms pursued by the European Commission and the member states found in the literature are:

- $\quad$ Single market in services: Monteagudo et al. (2012) find that the full implementation of the Services Directive would increase the EU GDP by $2.6 \%$. The analytical framework involves both a gravity equation and a general equilibrium model and identifies increased labour productivity as the main driver of the positive GDP effect. The benefits realised from the adoption of the Directive to 2012 are estimated at only $0.8 \%$ of EU GDP, implying an additional gain of $1.8 \%$ to be reaped. In a follow-up study, the European Commission (2015) assessed the reform effort from 2012 to 2014 and found a limited additional gain of $0.1 \%$ of EU GDP.

- Digital Single Market: Lorenzani and Varga (2014) find significant growth potential of both already implemented and planned digital structural reforms. Those already implemented could raise long-run GDP by $1 \%$, while the foreseen reforms in selected policy areas of the Digital Agenda for Europe could add $3.1 \%$ of EU GDP in the long run $(0.3 \%$ of EU GDP from radio spectrum policies, $0.4 \%$ from professional e-skills policies, $1.9 \%$ from e-commerce policies and $0.4 \%$ from fixed broadband policies). Civic Consulting (2011) find that completion of an EU-wide e-commerce market could raise EU GDP by $1.7 \%$, with two thirds of consumer welfare gains coming from increased consumer choice and one third from lower online prices. European Parliament (2014) finds that completion of the digital single market would raise EU GDP by $0.4 \%$.

- External trade agreements: CEPR (2013) uses a computable general equilibrium model to find that the proposed trade agreement between the United States and the European Union could increase EU GDP by $0.5 \%$ by 2027 . A joint study by the European Commission and the Government of Canada (2008) estimated that a trade deal between the EU and Canada could increase EU GDP by $0.1 \%$ in the long run. The European Commission (2012) estimated that a trade agreement between the EU and Japan could raise EU GDP by $0.3 \%$ in the long run. 
The analytical framework of Bourlès et al. (2010) is employed to assess the impact of pro-competition regulatory reforms. Multifactor productivity (MFP) is assumed to follow an error correction model (ECM) of the form:

$$
\Delta \ln M F P_{i, j, t}=a_{0} \Delta \ln M F P_{F, j, t}+a_{1} g a p_{i, j, t-1}+a_{2} R E G_{i, j, t-1}+a_{3} R E G_{i, j, t-1} \times g a p_{i, j, t-1}+f_{i}+f_{j, t},
$$

where $M F P_{i, j, t}$ is the MFP level of a non-frontier sector-country pair $i, j$ in year $t, M F P_{F, j, t}$ is the MFP level at the technological frontier $F$ for sector $i$ in year $t, R E G_{i, j, t}$ is the OECD's indicator of product market regulation - which measures regulatory burdens stemming from anti-competitive product market regulations in upstream sectors - in each country/sector/year triad, ${ }^{2}$ and gap $_{i, j, t}$ is the country-sector distance from the sector frontier in year $t$, defined as:

$$
\operatorname{gap}_{i j, t}=\ln \left(\frac{M F P_{F j, t}}{M F P_{i j, t}}\right) .
$$

$f_{i}$ and $f_{j, t}$ denote respectively sector and country-year fixed effects. Estimated coeffcients (over the 1995-2007 period for 24 OECD countries) ${ }^{3}$ indicate that the leader country's MFP growth and the gap between the leader country both have a positive impact on MFP growth in that same sector in less productive countries. More importantly, the indicator of regulatory burden has a negative influence on MFP growth $\left(a_{2}=-0.124\right)$. This effect is found to be even more negative for country/sector/period triads close to the technological frontier, as suggested by the positive coefficient on the interaction term $\left(a_{3}=0.132\right)$. This framework is used to estimate the MFP growth (thereby GDP growth implied from the supply-side) resulting from product market reforms that translate into a given percentage reduction in the OECD PMR indicator.

The effect of reforms on the European Union multifactor productivity is approximated by considering the five largest EU economies (France, Germany, Italy, Spain and United Kingdom and aggregating the effects obtained using 2014 GDP weights (constant prices, constant purchasing power parities and output approach). According to this approximation, ${ }^{4}$ the implementation of key recommendations listed in Table A.1 would lead to an increase in the level of total GDP by $0.4 \%$ after five years, compared to a situation, in which none of these reforms is implemented (Table A.3). The corresponding increase in the level of total GDP after ten years would be $0.7 \%$ (Table A.4).

2. Bourlès et al. (2010) calculated this indicator for each country by using total input-output coefficients as follows:

$$
R E G_{j, t}=\sum_{k} N M R_{k, t} \times w_{k, j},
$$

where $\mathrm{NMR}_{\mathrm{k}, \mathrm{t}}$ is the OECD indicator of anti-competitive regulation in non-manufacturing sector $k$ in year $t$ and the weight $\mathrm{w}_{\mathrm{k}, \mathrm{j}}$ (comprised between 0 and 1) is the total input requirement of sector $j$ for intermediate inputs from non-manufacturing sector $k$. This exercise adopts this approach to the change in the OECD indicator of an economy-wide stringency of PMR.

3. Column (4) of Table 1 in Bourlès et al. (2010).

4. Note that the sum of GDP of these five countries accounts for $68 \%$ of EU (28 countries) total GDP, therefore the effect found on these five countries can be considered a good approximation of the average effect that may materialise at the EU level if all the countries were to implement such reforms. 
Table A.3. Five-year impact on GDP ${ }^{1}$

Per cent of GDP

\begin{tabular}{lcccccc}
\multicolumn{1}{c}{ Area of reform } & Total & France & Germany & Italy & Spain & $\begin{array}{c}\text { United } \\
\text { Kingdom }\end{array}$ \\
\hline $\begin{array}{l}\text { Barriers to entrepreneurship - Barriers in } \\
\text { services }\end{array}$ & 0.17 & 0.16 & 0.17 & 0.33 & 0.13 & 0.06 \\
$\begin{array}{l}\text { Barriers to entrepreneurship - } \\
\begin{array}{l}\text { Communication and simplification of } \\
\text { rules and procedures }\end{array}\end{array}$ & 0.09 & 0.10 & 0.08 & 0.13 & 0.08 & 0.06 \\
Barriers in network sectors & 0.13 & 0.15 & 0.14 & 0.21 & 0.08 & 0.07 \\
Total & $\mathbf{0 . 3 9}$ & $\mathbf{0 . 4 1}$ & $\mathbf{0 . 3 9}$ & $\mathbf{0 . 6 6}$ & $\mathbf{0 . 3 0}$ & $\mathbf{0 . 2 0}$ \\
\hline
\end{tabular}

1. Aggregation using 2014 GDP weights (output approach, constant prices, constant purchasing power parities, OECD base year).

Table A.4. Ten year impact on GDP ${ }^{1}$

Per cent of GDP

\begin{tabular}{lcccccc}
\hline \multicolumn{1}{c}{ Area of Reform } & Total & France & Germany & Italy & Spain & $\begin{array}{c}\text { United } \\
\text { Kingdom }\end{array}$ \\
\hline $\begin{array}{l}\text { Barriers to entrepreneurship - Barriers in } \\
\text { services }\end{array}$ & 0.29 & 0.28 & 0.29 & 0.56 & 0.23 & 0.11 \\
$\begin{array}{l}\text { Barriers to entrepreneurship - } \\
\text { Communication and simplification of }\end{array}$ & & & & & & \\
rules and procedures & 0.15 & 0.17 & 0.14 & 0.22 & 0.14 & 0.11 \\
Barriers in network sectors & 0.23 & 0.27 & 0.25 & 0.35 & 0.15 & 0.13 \\
\hline Total & $\mathbf{0 . 6 7}$ & $\mathbf{0 . 7 2}$ & $\mathbf{0 . 6 7}$ & $\mathbf{1 . 1 3}$ & $\mathbf{0 . 5 2}$ & $\mathbf{0 . 3 5}$ \\
\hline
\end{tabular}

1. Aggregation using 2014 GDP weights (output approach, constant prices, constant purchasing power parities, OECD base year).

This quantification aims to provide only an order of magnitude estimate of the potential benefits of product market reforms, as it rests on a number of assumptions. For instance, since the PMR indicator is designed to capture domestic product market regulatory regimes, some of the recommendations that specifically refer to cross-border regulations cannot be directly translated into changes of the PMR. In these cases, an equivalent measure within the PMR structure has been used to proxy for the effect of such recommendations. As an example, the recommendation that suggests harmonising national regulations and technical specifications in network sectors, with the target of transferring decision powers in technical matters to a single EU regulator, has been considered equivalent to the PMR question referring to the change in the access of third party to the transmission grid from negotiated to regulated.

The magnitude of projected output gains is in line with similar exercises performed for other OECD countries (Bourlès et al., 2010, Bouis and Duval, 2011; Anderson et al., 2014). Based on the quantified PMR changes considered in the exercise, the biggest GDP improvement at both horizons is associated with removal of barriers to entrepreneurship in services. Removal of barriers in network sectors, including the EU commitment for more co-ordinated action in the energy and transport sectors made in the G-20 context is the second most important factor of the output gains, followed by simplification of rules and procedures and its positive effect on entrepreneurship. Although Italy and France appear as countries that stand to gain most from the implementation of product market reforms, the gains available to other countries are important in the current weak growth environment. 


\section{Bibliography}

Anderson, D., B. Barkbu, L. Lusinyan and D. Muir (2014), "Assessing the Gains from Structural Reforms for Jobs and Growth", Chapter 7 in IMF (2014), Jobs and Growth: Supporting the European Recovery, International Monetary Fund, Washington DC, www.imf.org/external/np/seminars/eng/2014/eurbook/pdf/7.pdf.

Bouis, R. and R. Duval (2011), "Raising potential growth after the crisis. A quantitative assessment of the potential gains from various structural reforms in the OECD area and beyond", OECD Economics Department Working Papers, No. 835, OECD Publishing, Paris, http://dx.doi.org/10.1787/5kgk9qj18s8n-en.

Bourlès, R., G. Cette, J. Lopez, J. Mairesse and G. Nicoletti (2010), "Do product market regulations in upstream sectors curb productivity growth? Panel data evidence for OECD countries", NBER Working Papers, No. 16520, National Bureau of Economic Research, Cambridge MA, http://dx.doi.org/10.3386/w16520.

CEPR (2013), "Reducing Transatlantic Barriers to Trade and Investment: An Economic Assessment", Centre for Economic Policy Research, London.

Civic Consulting (2011), "Consumer market study on the functioning of e-commerce and Internet marketing and selling techniques in the retail of goods", Report for the European Commission prepared by Civic Consulting, Berlin.

European Commission (2016), "The economic impact of selected structural reform measures in Italy, France, Spain and Portugal”, European Commission, Brussels, http://ec.europa.eu/economy_finance/publications/eeip/pdf/ip023_en.pdf.

European Commission (2015), "Economic Impact of the Services Directive: A 2014 update", European Commission, Brussels.

European Commission (2012), "Impact assessment report on EU-Japan trade relations", Commission Staff Working Document, European Commission, Brussels, http://trade.ec.europa.eu/doclib/docs/2012/july/tradoc_149809.pdf.

European Commission and Government of Canada (2008), "Assessing the costs and benefits of a closer EU-Canada economic partnership", A joint study by the European Commission and the Government of Canada, http://trade.ec.europa.eu/doclib/docs/2008/october/tradoc_141032.pdf.

European Parliament (2014), "The cost of non-Europe in the single market, part III - Digital single market", Report for the European Added Value Unit prepared by GHK, Brussels.

Lorenzani, D. and J. Varga (2014), "The Economic impact of digital structural reforms", Economic Papers, No. 529, European Commission, Brussels.

Monteagudo, J., A. Rutkowski and D. Lorenzani (2012), "The economic impact of the Services Directive: A first assessment following implementation", Economic Papers, No. 456, European Commission, Brussels.

Varga, J. and J. in 't Veld (2014), "The potential growth impact of structural reforms in the EU: A benchmarking exercise", Economic Papers, No. 541, European Commission, Brussels. 